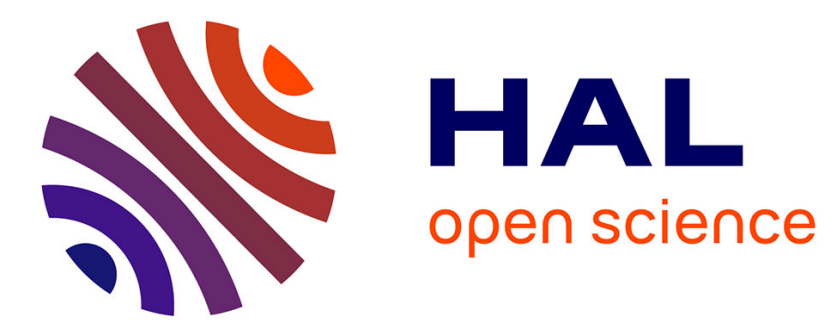

\title{
Evidence for deep gas loss in open volcanic systems
}

\author{
Marielle Collombet, Alain Burgisser, Mathieu Colombier, Elizabeth Gaunt
}

\section{To cite this version:}

Marielle Collombet, Alain Burgisser, Mathieu Colombier, Elizabeth Gaunt. Evidence for deep gas loss in open volcanic systems. Bulletin of Volcanology, 2021, 83 (2), 10.1007/s00445-020-01433-0 . hal-03369172

\section{HAL Id: hal-03369172 \\ https://hal.science/hal-03369172}

Submitted on 7 Oct 2021

HAL is a multi-disciplinary open access archive for the deposit and dissemination of scientific research documents, whether they are published or not. The documents may come from teaching and research institutions in France or abroad, or from public or private research centers.
L'archive ouverte pluridisciplinaire $\mathbf{H A L}$, est destinée au dépôt et à la diffusion de documents scientifiques de niveau recherche, publiés ou non, émanant des établissements d'enseignement et de recherche français ou étrangers, des laboratoires publics ou privés. 


\section{Evidence for deep gas loss in open volcanic systems}

2

3 Marielle COLLOMBET $^{\mathrm{a} *}$, Alain BURGISSER ${ }^{\mathrm{a}}$, Mathieu COLOMBIER ${ }^{\mathrm{b}}$, Elizabeth GAUNT ${ }^{\mathrm{c}}$

4

5 a Univ. Grenoble Alpes, Univ. Savoie Mont Blanc, CNRS, IRD, IFSTTAR, ISTerre, 38000 Grenoble, France.

6 b Department of Earth and Environmental Sciences, Ludwig-Maximilians-Universität München, Germany.

$7 \quad$ c Instituto Geofísico, Escuela Politécnica Nacional, Quito, Ecuador.

8

9 Abstract: 207 words, Main text: 5000 words, 9 Figures, 56 references.

\section{0}

$11 *$ Corresponding author: marielle.collombet@univ-smb.fr

\section{2}

\section{Acknowledgements}

15 We thank Nicolas Gillet for the time spent to help with proper uncertainties calculations. We also thank the

16 thoughtful and detailed comments of two anonymous reviewers and the constructive editorial handling of $\mathrm{K}$.

17 Cashman. This work was partially supported by the Agence Nationale pour la Recherche grant ANR-19-

18 CE31-0007. 


\section{Abstract}

21 Previous studies of Vulcanian eruptive products have shown that the respective volcanic conduits were filled

22 for the most part with low-porosity magma (i.e. $<10$ vol\%) prior to eruption. Comparison with the 23 theoretical porosity distribution expected from closed-system degassing suggests that gas loss must have 24 taken place at depth within the magmatic column (between 3 and $5 \mathrm{~km}$ ). At such high pressures (between 70 25 and $110 \mathrm{MPa})$, however, porosities are low enough $(<20 \mathrm{vol} \%)$ to rule out traditional gas loss mechanisms.

26 We tested if channelling, an outgassing mechanism based on bubble connection due to high crystal content 27 ( $>40$ vol\%) proposed to occur in mushy magma reservoirs, could also happen in volcanic conduits. We 28 reanalysed phenocryst, microlite, and porosity data from recent eruptions of Merapi volcano, Indonesia, 29 Soufrière Hills volcano, Montserrat, and Tungurahua volcano, Ecuador. Overall, these magmas had crystal 30 contents high enough for outgassing to occur by channelling. Gases could be channelled out of the magma 31 columns at various levels during ascent to yield mostly gas-depleted magma columns prior to explosive 32 behaviour. Such outgassing by channelling thus has the capacity to influence eruptive style. Depending on 33 the phenocryst content, microlite growth during ascent can either foster, or impede gas escape by 34 channelling. Considering the pervasive occurrence of microlites and ensuing high crystal contents in 35 volcanic conduits (between 40 and $70 \mathrm{vol} \%$ ), the high likelihood of channelling implies that other outgassing 36 mechanisms might not be as dominant as previously envisioned.

\section{Keywords: Silicic volcanoes, outgassing, crystal content, channelling, porosity}

\section{Introduction}

40 The eruption of viscous magma at the Earth's surface often gives rise to abrupt regime changes, such as the

41 transition from the gentle effusion of a lava dome to brief but powerful Vulcanian explosions. These eruptive

42 regimes are controlled by outgassing, a process by which the gas contained in bubbles formed during ascent

43 can escape from the magma. In the case of highly viscous magmas (viscosity $>10^{6}$ Pa.s), individual bubbles

44 are trapped within the melt and cannot migrate individually through the magmatic column, hindering the 45 bubbly flow outgassing mechanism that is generally at play for low viscosity magmas (Parmigiani et al. 46 2016; Cardosso and Woods, 1999). Gas loss within highly viscous magmas is mainly related to bubble 
47 connectivity and to percolation, which controls the ability for the gas to travel through these bubble 48 connections, making the magma permeable under specific physical conditions. Pavourable physical 49 conditions for percolation to occur depend on the amount, size, and shape of the bubbles, deformation, which 50 promotes bubble connectivity (e.g., Blower 2001; Rust and Cashman 2004; Burgisser et al. 2017; Kushnir et 51 al. 2017), and the presence of crystals (Lindoo et al. 2017; deGraffenried et al. 2019; Degruyter et al. 2019;

52 Colombier et al. 2020). In some cases, brittle failure and cracks can also appear (Shields et al. 2014). When 53 quantified, permeabilities deduced from the combination of these parameters range between $10^{-15}$ and $10^{-12}$ 54 m² (e.g., Klug and Cashman, 1996; Farquharson et al. 2015; Kushnir et al. 2016; Burgisser et al. 2017). 55 When integrated into numerical models, they contribute to reproduce effusive regimes that are compatible 56 with field observations like bubble density distribution described on an eroded conduit, or extrusion rate 57 during dome-forming activity (e.g., Melnik and Sparks, 2002; Collombet, 2009; Degruyter et al. 2012; 58 Cassidy et al. 2018).

60 However, these numerical models fail to reproduce the very low porosity values inferred to occur in the 61 conduit prior to Vulcanian eruptions. Figure 1 shows the porosity distribution prior to the Vulcanian 62 explosion on February 10, 2010 at Soufrière Hills volcano, Montserrat (Burgisser et al. 2019). Samples 63 collected in the field provide porosity data down to approx. $70 \mathrm{MPa}(\sim 3 \mathrm{~km}$ depth) that are significantly 64 below the theoretical porosities suggested for a closed system. The outgassing mechanisms, which are based 65 on bubble connection relationships implemented in various numerical models, could explain low porosity 66 values near the surface but fail to reproduce porosity values at depth (beyond a corresponding pressure of 10 $67 \mathrm{MPa}$ ). This implies that another outgassing mechanism is at play and/or that a large amount of gas has been 68 evacuated from the deepest parts of the magma column (most likely above $70 \mathrm{MPa}$ ) during and/or before the 69 ascent from the reservoir.

71 We test the hypothesis that this mismatch is due to a missing physical mechanism that greatly enhances 72 outgassing efficiency within the conduit, even at very low porosity values $(<10 \mathrm{vol} \%)$. This mechanism, 73 channelling, which involves a rigid crystal framework, was first described for the case of magma chambers 74 by Parmigiani et al.(2017) and Degruyter et al. (2019). Channelling relies on the capacity of crystal-rich 
75 magmas to build sustainable channels for gas percolation independently from magma movements. For

76 crystal volume fractions between 40 and 70 vol\%, this mechanism allows gas permeability to reach the order

77 of $10^{-10} \mathrm{~m}^{2}$, which is two to five orders of magnitude higher than permeability calculated for bubbles alone at

78 an equivalent porosity (Klug and Cashman, 1996; Burgisser et al. 2017). Under such permeable conditions, it

79 is much more plausible that magma succeeds to extensively degas and outgas, even at the high pressures and

80 low gas volume fractions typical of the deepest parts of a volcanic conduit. In addition, the formation of such

81 channel-like porous pathways reduces significantly the percolation threshold, which is the critical

82 vesicularity at which system-spanning bubble connectivity and permeability occur (e.g., Lindoo et al. 2017;

83 Colombier et al. 2020). As a consequence, provided that crystallinity is high enough, outgassing can occur

84 before or early during ascent, resulting in a magma column severely depleted in gas.

86 We revisited three data sets of the porosity distribution within volcanic conduits filled by andesitic magmas.

87 They are from a Vulcanian explosion on February 11, 2010 at Soufrière Hills volcano, Montserrat (Burgisser

88 et al. 2019), an explosive event on October 26, 2010 at Merapi volcano, Indonesia (Drignon et al. 2016), and

89 a large Vulcanian event that occurred on July 14, 2013 at Tungurahua volcano, Ecuador (Gaunt et al. 2020).

90 We show that the magmas feeding these Vulcanian events were crystal-rich enough to promote highly

91 efficient outgassing by channelling.

92

\section{Geological Context}

94 The on-going eruption of Soufrière Hills is dominated by lava dome effusion with intermittent collapse. The

95 magma emitted is andesitic in bulk composition with a rhyolitic melt. The fifth phase of lava extrusion since

96 the beginning of the eruption was marked by a succession of dome growth as lava lobes and spines followed

97 by partial dome collapse (Wadge et al. 2014b; Cole et al. 2014). The February 11, 2010 explosion was

98 preceded by two small Vulcanian events on February 5 and 8 (Stinton et al. 2014b; Cole et al. 2015). The

99 February 11 event was mostly likely triggered by a dome collapse that started 1 hour and 27 minutes prior to

100 the onset of the Vulcanian explosion. Burgisser et al. (2019) analyzed twenty-three samples of the resulting

101 pumice-rich, pyroclastic density current deposits and pumice fallout deposits. Phenocrysts are mostly 
102 plagioclases that are up to $5 \mathrm{~mm}$ across (Higgins and Roberge, 2003). Large plagioclases have irregular

103 shapes and smaller plagioclases are euhedral. Euhedral amphiboles up to $12 \mathrm{~mm}$ across are also present with 104 a low number density. Microlites are mostly plagioclases with a concave up distribution in the $20-1000 \mu \mathrm{m}^{2}$ 105 range (Couch et al. 2003) and short/long axis ratios of $\sim 0.5$ (Murch and Cole, 2019).

107 Merapi volcano produced in 2010 the largest explosive eruption since 1872 (Surono et al. 2012). This 108 unusual event, which emitted basaltic andesites with a rhyolitic melt (Costa et al. 2013), occurred in several 109 stages between October 26 and November 23 (Komorowski et al. 2013; Jenkins et al. 2013). The first large 110 explosion lasted for $2 \mathrm{~h}$ on October 26, producing an ash plume and pyroclastic density currents. This 111 explosion had a phreatomagmatic component and was interpreted as a laterally directed explosion from a 112 newly formed cryptodome. Drignon et al. (2016) analyzed forty-one samples from a pumice levee of the 113 valley-filling pyroclastic deposits produced by the October 26 event. Phenocrysts populations vary little 114 between the recent eruptions (van der Zwan et al. 2013). Crystals that are 1.6-4 mm across make up one 115 population with a size distribution that is approximately a straight line. The most common phenocrysts are 116 plagioclases and pyroxenes that both have subhedral morphologies with evidences of resorption (Erdmann et 117 al. 2016). Microlites are mostly plagioclases with a rectangular prism habit, areas of $10-15 \mu \mathrm{m}^{2}$, and 118 short/long axis ratios ranging from 0.35 to 0.67 (Costa et al. 2013).

120 The latest activity (1999 - 2016) at Tungurahua volcano varied from small-scale gas and ash venting and 121 Strombolian outbursts to rare sub-Plinian events (Eychenne et al. 2012; Hall et al. 2015; Battaglia et al. 122 2019). The magma emitted is a low silica andesite with a high silica andesitic melt. The last six years of this 123 eruptive phase was marked by two to three months of relative quiescence followed by Vulcanian events and 124 ending with several weeks of low-explosivity Strombolian activity and ash venting (Hidalgo et al. 2015). On 125 July 14, 2013, an unusually large Vulcanian event occurred at 06h46 (local time), producing a large ash 126 column and pyroclastic density currents that travelled up to $7.5 \mathrm{~km}$ away from the vent. Gaunt et al. (2020) 127 analyzed twenty-seven samples from three lithological groups (pyroclastic current deposits, fallout pumice, 128 and ballistic ejecta) present in the ejecta. Plagioclase is the most abundant phenocryst phase, followed by 129 pyroxene (Samaniego et al. 2011). Both exhibit mostly euhedral habits. Microlites are mostly plagioclase 
130 with habits ranging from rectangular prisms to acicular crystals (Gaunt et al. 2020). Dense plug rocks have 131 mean microlite areas of $4.2-26 \mu \mathrm{m}^{2}$ with mostly tabular morphologies. Juvenile vesicular clasts of the 132 pyroclastic current deposits have mean microlite areas of 10-66 $\mu \mathrm{m}^{2}$ with occasional swallow-tail and 133 hopper morphologies.

\section{Methods}

136 We modified data treatment of the recompression model of Burgisser al. (2010) used by Drignon et al. 137 (2016), Burgisser et al. (2019), and Gaunt et al. (2020). We briefly outline the data acquisition and the data 138 treatment done in these three studies before describing our modification. The petrological and textural

139 analysis of the samples was carried out in the three studies according to the procedures outlined in Burgisser 140 al. (2010) and Drignon et al. (2016). Polished sections were imaged by Scanning Electron Microscopy 141 (SEM) or by element mapping based on Energy Dispersive Spectroscopy (EDS). Images were taken at 142 several magnifications depending on the average size of the vesicles and crystals. Images were used to 143 quantify the amounts of vesicles, glass, phenocrysts, and microlites in the samples by manually tracing each 144 of the elements (SEM) or by automatic thresholding and by successive subtractions of Boolean combinations 145 of the binary images of the analyzed elements (EDS). The segmented images were then used to measure the 146 proportions of phenocrysts, microlites, and vesicles. In this study, we use "vesicles" and "vesicularity" to 147 characterize voids regardless of genesis. We use "bubbles" and "porosity" to characterize voids resulting 148 from the exsolution of magmatic volatiles.

Imaged vesicles were subdivided in four types (Fig. 2, Burgisser et al. 2010; Giachetti et al. 2010). The

151 first type was composed of large, deformed vesicles of equivalent diameter $>300 \mu \mathrm{m}$ and circularity $<0.2$.

152 The second type was composed of small, rounded vesicles of equivalent diameter $<40 \mu \mathrm{m}$ and circularity $153>0.65$. The third type was composed of large angular voids between crystal fragments and of irregular voids 154 delimited by crystal faces that are found in dense, diktytaxitic samples. The last type was composed of the 155 remaining vesicles, which are of intermediate sizes and often composed of coalesced bubbles. Type 1 156 vesicles were caused by degassing during magma ascent from the reservoir. The sudden decompression 
157 linked to the explosion nucleated new, syn-explosive bubbles. The first syn-explosive bubbles are of Type 4

158 because they had enough time to grow and coalesce before quenching. The latest syn-explosive bubbles are

159 of Type 2 because they were quenched as small, isolated vesicles. Finally, Type 3 vesicles that are gaps

160 between crystal fragments result from crystal failure caused by the decompression accompanying conduit

161 evacuation. The remaining Type 3 vesicles found in diktytaxitic samples are likely due to reorganization of

162 voids under shear (Laumonier et al. 2011).

163

164 The recompression model of Burgisser al. (2010) assumes that, prior to explosion, the piece of magma to be 165 ejected is at a pressure $P_{i}$ and porosity, $\phi$, with water weight fraction distributed as exsolved, $x_{i}$, and 166 dissolved, $s_{i}$. The clast is quenched at pressure $P_{q}$, porosity $\phi_{q}$, and dissolved water content, $s_{q}$. Quench 167 porosity, $\phi_{q}$, is the sum of volume fractions of the four vesicle types. Only Type 1 vesicles were present in the 168 conduit prior to the explosion. Type 2 vesicle nucleate during the explosion but were not affected by 169 outgassing. Type 3 and 4 vesicles both appeared during the explosion and could participate to outgassing 170 because they feature various degrees of interconnection. The weight fraction of the exsolved water content at 171 quench time is thus composed of an outgassed part, $x_{\text {out }}$, and a part remaining within the clast that is divided 172 into three weight fractions: $x_{q 1}$ (Type 1 vesicles), $x_{d 1}$ (Type 2 vesicles), and $x_{q 2}$ (Type 3 and 4 vesicles).

173 Similarly, quench pressures differ from pre-explosive pressures. The conversion from quench to pre-

174 explosive conditions (Fig. 2) was done by a mass balance linking the state of the magma just before the 175 explosive event (pre-explosive state characterized by $P_{i}, \phi, s_{i}$ and $x_{i}$ ) to that once the magma has quenched 176 (quench state characterized by $P_{q}, \phi_{q}, s_{q}, x_{q 1}, x_{d 1}$, and $x_{q 2}$ ).

Model input data are the magma temperature, the densities of melt and crystals at that temperature, $\phi_{q}$,

179 and, to obtain $P_{i}$, one of plagioclase microlite content, or glass water content. In Gaunt et al. (2020), $P_{i}$ was

180 obtained by converting the glass-referenced volume proportions of plagioclase microlites of each sample into 181 pressure. In Drignon et al. (2016) and Burgisser et al. (2019), $P_{i}$ was calculated by using the glass water 182 content determined by elemental analyzer and converting successively glass water content into dissolved 183 water content and into pressure with a solubility relationship. The original recompression model has four free 184 parameters (Burgisser et al. 2010). The first one, $O=x_{o u t} /\left(x_{q 1}+x_{q 2}+x_{d 1}+x_{o u t}\right)$, quantifies the gas fraction 
185 outgassed during the explosion to propel the ejecta. This poorly constrained parameter, which has a modest

186 effect on pre-explosive values (Burgisser et al. 2010), is assumed to lie between $10 \%$ and $70-82 \%$ with a

187 reference value of $50 \%$. The second parameter, $H$, estimates the maximum, near-instant pressure drop that

188 clasts can sustain before breaking (Mueller et al. 2008) as a proxy for quench pressure. In other words, $P_{q}$ is

189 the smallest of $P_{i}$ and $P_{a t m}+H P_{\text {Mueller, }}$, where $P_{\text {atm }}$ is the atmospheric pressure, $P_{\text {Mueller }}$ is the value of the

190 pressure drop, and $H$ is a multiplicative factor that was assumed to lie between 0.5 and 2 with a typical value

191 of 1 . The upper limits of $O$ and $H$ were chosen so that the maximum total water content of every clast lies

192 below that inferred in the reservoir and that all clasts undergo syn-explosive inflation so as to match textural

193 observations. The upper values of $O$ were 70, 76, and 82\% for Tungurahua, Soufrière Hills, and Merapi,

194 respectively. The two last parameters of the model quantify the proportions of vesicles: $E=\left(x_{d 1}+x_{q 2}\right) / x_{q 1}$ and

$195 F=x_{d 1} / x_{q I}$. As vesicle types occur in similar proportions in the products of a given explosion, Burgisser et al.

196 (2010) and the authors of the three data set studied herein (Drignon et al. 2016; Burgisser et al. 2019; Gaunt

197 et al. 2020) used a lumped approach; they averaged vesicle proportions in all samples of a given explosion.

198 They then calculated $E$ and $F$ using the median proportions and standard deviations of each vesicle type.

200 In this study, we attempted to gain precision in the pre-explosive porosities by considering for each clast the 201 respective proportions of the vesicle types. These proportions were published in the original studies. Using 202 individual vesicle proportions means that $E$ and $F$ were no longer considered as free parameters with a 203 median value and a standard deviation. Instead, they were considered as input parameters with an assumed 204 negligible uncertainty, which reduced the number of degrees of freedom of the recompression procedure 205 from four to two. In the Drignon et al. (2016) study of the October 26 event at Merapi, for instance, the 206 vesicles of Types 1, 2, and 3-4 were present in respective median proportions of 28.4:2.5:70, which yields $207 E=2.7$ and $F=0.14$. We replaced these median proportions by the individual values of each sample (AME 10 208 A1: 33.5:3.1:63.4, etc.) to obtain $E$ and $F$ values for each sample. Beyond reducing the number of sources of 209 uncertainties, this modification evidenced a shortcoming of the vesicle size distribution analysis, which led 210 us to discard data from Drignon et al. (2016) (Supplementary Text S1). 
212 The recompression model has two types of uncertainty. Analytical uncertainties result from error propagation 213 of the uncertainties on quench vesicularities, glass water contents, and plagioclase microlite proportions. 214 Analytical uncertainties for each sample were calculated with four sets of model outputs that used the 215 reference values of $H$ and $O$ and the respective minimum and maximum values of $\phi$, microlite content and/or 216 glass water content. Analytical errors on pre-explosive porosity are small in absolute value ( $<1 \mathrm{vol} \%)$. Our 217 new procedure with fewer free parameters does not significantly affect these absolute errors $(<15 \%)$. 218 Similarly, errors on pre-explosive pressure are modified by $<10 \%$ and typically by $<2 \%$. These changes will 219 not be discussed further as they are smaller than those stemming from model uncertainties. This second type 220 of uncertainty results from propagation of the uncertainties on $H$ and $O$. The reference values and bounds of 221 these two parameters were combined to yield five sets of pre-explosive pressures and porosities. The set with 222 the reference values was kept as the average set and the two sets with the largest and smallest porosity values 223 at any pressure were kept as extrema to characterize model uncertainty. Only these three sets are reported in 224 the Results section.

226 In the case of a rigid crystal network with crystal volume fraction $\phi x$ between 0.4 and 0.7 , the minimum 227 porosity required to make percolation possible (i.e. the percolation threshold), $\phi_{\text {cr }}$ (Fig. 2), follows a third228 degree polynomial equation-:

$229 \phi_{c r}=a \phi_{x}^{3}-b \phi_{x}^{2}+c \phi_{x}+d$

230 where the constants are $a=0.7495, b=0.4268, c=-0.1626$, and $d=0.1478$ for Degruyter et al. (2019) or $a=2.75$, $231 b=2.79, c=0.6345$, and $d=0.0997$ for Parmigiani et al. (2017). The difference between these two sets of 232 constants is due to the initial conditions chosen for the bubbles. In the case of Parmigiani et al. (2017), the 233 initial positions of the bubbles and their respective size was set randomly, whereas these parameters followed 234 a spinodal distribution in the case of Degruyter et al. (2019). A spinodal distribution means that the size and 235 the position of bubbles satisfy the principle of mass conservation and capillary stresses, which leads to more 236 consistent and more accurate initial conditions. This higher level of physical verisimilitude led us to use the 237 set of parameters of Degruyter et al. (2019).

239 The vesicle-free crystal content, $\phi_{\mathrm{xvf}}$, is related to $\phi_{\mathrm{x}}$ by (Fig. 2): 
$240 \phi_{x}=(1-\phi) \phi_{x v f}$

241 Drignon et al. (2016) reported bulk volume fractions of vesicles, phenocrysts and microlite, from which $\phi_{x v f}$

242 (Table 1) was calculated using Eq (2). Burgisser et al. (2019) reported $\phi_{q}$ and $\phi_{x v}$. We used their original

243 unpublished quantifications of microlites to obtain vesicle-free volume fractions of phenocrysts. Gaunt et al.

244 (2020) reported bulk volume fractions of vesicles, of plagioclase and pyroxene phenocrysts, and of 245 plagioclase and pyroxene microlite. We used their original unpublished quantifications of oxide phenocrysts

246 and microlites to calculate $\phi_{x v}$.

247

248 For a given vesicle-free crystal content, there is one critical porosity such that $\phi=\phi_{\text {cr: }}$ :

$249 a(1-\phi)^{3} \phi_{x v f}^{3}-b(1-\phi)^{2} \phi_{x v f}^{2}+c(1-\phi) \phi_{x v f}+d-\phi=0$

250 For each $\phi_{\mathrm{xvf}}$ within the $40-70 \%$ interval, we solve equation (3) to obtain a solution $\phi_{\mathrm{cr}}=f\left(\phi_{\mathrm{xv}}\right)$. The associated

251 uncertainties, $d \phi_{\mathrm{xv}}$, were obtained by error propagation and mostly reflect natural variability. Uncertainties

252 on the critical porosity, $\mathrm{d} \phi_{\mathrm{cr}}$, were calculated using the variation of the $f$ function: $\mathrm{d} \phi_{\mathrm{cr}}=\mathrm{d} f\left(\mathrm{~d} \phi_{\mathrm{xvr}}\right)$.

\section{Results}

255 Considering the vesicle proportions of each sample instead of an average value does not change much $256(<17 \%)$ the final values of pre-explosive pressures (Fig. S1). When using microlites (Gaunt et al. 2020), no 257 pressure change occurs because the power-law relationship linking microlite proportion to pressure does not 258 depend on vesicle content. Pre-explosive porosities are more influenced by this reduction of free parameters.

259 Samples located at pressures $>10 \mathrm{MPa}$ change by $<10 \%$ from the original value. Shallower samples undergo 260 porosity changes of up to $25 \%$ with one outlier at $40 \%$ (Fig. S2), but the general trend with pressure remains 261 (Fig. S1). Changes in model uncertainties compared to the ones from the original studies are small but 262 uneven between data points, varying by $<15 \%$ from the original value except for a couple of samples with 263 vanishing porosity. As a result, the overall respective envelopes of model uncertainties are similar for each 264 volcano. 
266 Two conditions need to be met for outgassing to occur by channelling (Parmigiani et al. 2017; Degruyter et 267 al. 2019). The first condition is that total crystal content must be between 40 and 70 vol\%. Provided the 268 germane amount of crystals, the second condition is that a critical porosity is reached. Channelling allows 269 gas escape at very low gas volume fraction with a percolation threshold below 10 vol\%. We used the critical 270 values given by the empirical relationship of Degruyter et al. (2019) because they correspond to more 271 realistic initial conditions, but similar results are found when using the Parmigiani et al. (2017) values. To 272 take the empirical nature of these fits into account, we also considered the maximum and minimum 273 percolation values they yield within the validity bounds of crystal content ( 5 and 12 vol\% porosity, 274 respectively). Once channelling is established, outgassing rate is controlled by a balance between magma 275 permeability, driving pressure, and the collapse rate of the medium. As a result, outgassing could evacuate 276 more gas than the critical porosity. Such hysteresis has been proposed to occur at low (Rust and Cashman, 277 2004; Michaut et al. 2009; Gonnermann et al. 2017) and high crystal contents (Colombier et al. 2020), albeit 278 not by channelling. In the absence of more specific evidence, we considered that non-vanishing porosities 279 lower than the percolation threshold could result from channel collapse.

281 To test if channelling could explain low porosity distributions within volcanic conduits before explosion, we 282 assessed to which extent these two conditions of crystallinity and porosity were met in three sets of data on 283 andesitic products from different volcanoes. These datasets are composed of the pressures associated with 284 the corresponding pre-eruptive porosities and of the amounts of phenocrysts (which are generally already 285 present in the magmatic chamber) and microlites (which develop during magma ascent). It is important to 286 consider these two populations of crystals since they could, depending on how their amounts change during 287 ascent, prevent or enhance channelling.

\section{Montserrat}

290 The amounts of "phenocrysts" and "phenocrysts plus microlites" in the Soufrière Hills samples from 2010 291 are plotted in Fig. 3a. Microlite crystallization during ascent increased the total amount of crystals from 30 292 vol\% to approximatively 55 vol\% on average, thereby helping channelling to develop. Figure $3 \mathrm{~b}$ shows pre- 
293 explosive porosities of the samples, of closed-system degassing, and of the channelling threshold. All 294 threshold porosities are within a narrow range smaller than 5 vol\%. Considering that all samples have a 295 porosity well below that of closed-system degassing, it means that most of the gas present in the conduit has 296 been lost. Physical conditions propitious to channelling were thus probably met during ascent. However, it 297 appears that most measured porosities are slightly below the threshold values, except two points among the 298 shallowest samples and one point around $57 \mathrm{MPa}$ that are slightly above threshold. This situation indicates

299 that, if channelling occurred, a little more than the gas in excess of the threshold value has been lost, 300 deflating the magma back below the critical porosity.

\section{Merapi}

302 Data from the October 26, 2010 Merapi eruption are particularly interesting because they provide 303 information down to $\sim 10 \mathrm{~km}$ (270 MPa), which is close to the pure water exsolution level for that eruption 304 (Erdmann et al. 2016; Drignon et al. 2016). Estimating the exsolution level at Merapi is a complex task 305 because 1) a significant amount of $\mathrm{CO}_{2}$ coexisted with $\mathrm{H}_{2} \mathrm{O}$ in the gas phase and 2) the magmas feeding the 3062010 eruption were stored at multiple levels and mixed prior to their final ascent towards the surface (Costa 307 et al. 2013; Nadeau et al. 2013; Preece et al. 2014; Erdmann et al. 2016; Widiyantoro et al. 2018). The 308 mixing process started by magma assembly at depth and continued during ascent. This induced complexities 309 in the crystal cargo that hinders straightforward interpretations of porosity and crystal contents 310 (Supplementary Text S2). Here, we framed the likely conduit conditions according to the experimental 311 results of Erdmann et al. (2016) by performing two closed-system, multicomponent decompressions. 312 Following Drignon et al. (2016), we used the model D-Compress (Burgisser et al. 2015) to simulate the 313 porosity evolution of rhyolitic melts undergoing isothermal, equilibrium decompression at NNO+1. The first 314 decompression represents the hotter recharge magma at $975^{\circ} \mathrm{C}$. It starts from $250 \mathrm{MPa}$ with $5 \mathrm{wt} \%$ melt $\mathrm{H}_{2} \mathrm{O}$ 315 content and 400 ppm melt $\mathrm{CO}_{2}$ content, which yields a $\mathrm{CO}_{2} / \mathrm{H}_{2} \mathrm{O}$ molar ratio of 0.2 . The second represents 316 the colder resident magma at $925^{\circ} \mathrm{C}$. It starts from $175 \mathrm{MPa}$ with $3 \mathrm{wt} \%$ melt $\mathrm{H}_{2} \mathrm{O}$ content and $500 \mathrm{ppm}$ melt $317 \mathrm{CO}_{2}$ content, which yields a $\mathrm{CO}_{2} / \mathrm{H}_{2} \mathrm{O}$ molar ratio of 0.66 . The resident and recharge magmas were mixed in 318 a way that we expect to fall within these two end members. The initial porosity is mostly unconstrained, so 319 we considered a small ( $<<1$ vol\%) and a large (10 vol\%) value for each magma. 
321 Figure 4a shows the phenocrysts and total crystal content for Merapi conduit prior to the October 26

322 explosion. Unlike at Soufrière Hills, phenocrysts alone are already within the range for which channelling is

323 possible. The amount of crystals already present in reservoir(s) was thus sufficient to foster outgassing at

324 depth without magma ascent if sufficient gas was present. There was also enough time for the awakened

325 reservoir to degas during the weeks to months prior to eruption (Budi-Santoso et al. 2013). If microlites are

326 taken into account, however, the total crystal content clearly rises above 70 vol\% in most of the magmatic

327 column. Thus, if outgassing occurred by channelling, this outgassing mechanism took place earlier or during

328 the first phase of microlite crystallization. Once 70 vol\% of crystals was reached, channelling mostly likely

329 stopped.

331 Pre-eruptive porosities, percolation thresholds, and associated uncertainties are shown in Fig. 4b. Above $\sim 70$

$332 \mathrm{MPa}$, samples suggest that the conduit was filled with nearly gas-free magma, well below percolation 333 threshold. This observation makes the two scenarios starting with high initial porosities unlikely, so they 334 were not given further consideration. Assuming that the porosity evolution was controlled by an initially gas335 poor recharge magma, no bubbles are expected at pressures higher than $250 \mathrm{MPa}$, which is consistent with 336 the very small values $(<1 \mathrm{vol} \%)$ of the samples located around that pressure. At $\sim 150 \mathrm{MPa}$, the gas available 337 by closed-system degassing matches that needed for channelling (black line on Fig. 4b) although measured 338 porosities are well below percolation. Assuming instead that the eruptive products sampled the resident 339 magma brings the pressure at which closed-system porosities are within the threshold range from 150 to 70 $340 \mathrm{MPa}$ (green line on Fig. 4b). This situation is compatible with the vanishing measured porosities at higher 341 pressure and the fact that porosities increase below $70 \mathrm{MPa}$ while remaining below the threshold porosities.

343 The combined data of Figs. 4a and $4 \mathrm{~b}$ suggest that deeper than $3 \mathrm{~km}$ (70 MPa), there was not enough gas 344 available in the reservoir to be outgassed despite the favourable phenocryst content for channelling. Between $3453 \mathrm{~km}$ and the surface, however, gas contents stemming from closed-system degassing would have been high 346 enough for outgassing to occur. Shallower than $3 \mathrm{~km}$, crystal contents vary from $40-50 \mathrm{vol} \%$ before 347 microlite crystallization, to more than $70 \mathrm{vol} \%$ post-crystallization. If the shallow magma column stagnated 
348 while (or before) microlite crystallization occurred, channelling could have started before microlite

349 crystallization and continued until 70 vol\% of crystals was reached. If the magma still contained substantial 350 gas volume fraction once this high limit of crystallinity reached, other mechanisms, such as cracks due to 351 brittle failure of the melt, should be evoked to explain further outgassing. In any case, the degassing trends

352 suggest that the analysed clasts sampled the colder resident magma. As in the case of Soufrière Hills, pre353 eruptive shallow samples display porosities below the critical threshold, possibly suggesting outgassing 354 accompanied by deflating.

\section{Tungurahua}

356 Storage conditions at Tungurahua were more $\mathrm{H}_{2} \mathrm{O}$-rich than at Merapi, with a molar fraction of $\mathrm{H}_{2} \mathrm{O}$ in the 357 gas phase of 0.8 (Andújar et al. 2017). As a result, D-Compress runs with mixed $\mathrm{H}_{2} \mathrm{O}-\mathrm{CO}_{2}$ fluids do not 358 differ much from pure $\mathrm{H}_{2} \mathrm{O}$ ones, and closed-system decompressions with pure water were assumed instead 359 for simplicity. Porosities and crystal contents from Tungurahua give information from the surface down to $\sim 7$ $360 \mathrm{~km}$ depth (170 MPa), which, like at Merapi, is deep enough to constrain the point at which gas loss starts. 361 Similarly to Soufrière Hills, phenocrysts in the Tungurahua magma cannot trigger channelling alone (Fig. 362 5a). The total amount of crystals, however, approaches the lower limit of $40 \%$ around $100 \mathrm{MPa}$, and exceeds 363 it for pressures lower than $50 \mathrm{MPa}$. This implies that microlites were required for channelling to occur 364 possibly around $100 \mathrm{MPa}$, and more certainly around $50 \mathrm{MPa}$. Near the surface, the upper limit of $70 \%$ is 365 overcome, stopping channelling and potentially fostering a shallow gas-rich area that appears clearly on the 366 porosity data with values spanning from $25 \%$ to $50 \mathrm{vol} \%$ (Fig. $5 \mathrm{~b}$ ). Closed-system porosities suggest that gas 367 was available for channelling at $\sim 150 \mathrm{MPa}$, although the amount of crystals was not sufficient at this depth to 368 foster channelling (Fig. 5a). The first calculated pre-eruptive porosity approaching the channelling threshold 369 is located around $110 \mathrm{MPa}$ and the first pre-eruptive porosity which effectively coincides with that threshold 370 appears at $\sim 50 \mathrm{MPa}$ (Fig. 5b). As a result, gas loss by channelling may have started between 110 and $50 \mathrm{MPa}$ 371 and was no longer possible below $10 \mathrm{MPa}$.

\section{Discussion}


374 Our data show that, to first order, channelling is a process that is consistent with the low porosities inferred 375 in volcanic conduits prior to Vulcanian explosions. That channelling can occur during ascent due to an 376 increase in crystal content brings a partial answer to the long-standing issue of gas transfer across the entire 377 depth of magmatic systems (e.g., Oppenheimer et al. 2009) despite sometimes very high magma viscosity 378 and no obvious physical mechanism of transfer (Edmonds et al. 2010). Gas percolation in magmas has long

379 been studied in decompression experiments, which have notably shown that the presence of $>20$ vol\% 380 crystals lowers percolation thresholds compared to crystal-poor melts (Lindoo et al. 2017; deGraffenried et 381 al. 2019). Such type of viscous percolation occurs when bubbles can expand spherically while pushing 382 crystals apart (Colombier et al. 2020).

384 The percolation associated with channelling, on the other hand, is fostered by buoyancy-driven deformation 385 of the bubbles in the constricted space between crystals and subsequent coalescence at moderate to low Bond 386 numbers. Additional processes can also form similar channel-like interconnected porous pathways at low 387 critical porosity in crystal-rich magmas. For instance, Colombier et al. (2020) showed that brittle-viscous 388 coalescence is favoured at melt viscosities higher than $10^{6} \mathrm{~Pa}$.s and relatively high gas overpressure. Because 389 of such alternatives, conditions adverse to channelling do not imply the absence of outgassing. Figure 7 390 shows a literature compilation of vesiculation experiments on crystal-free to crystal-rich magmas and magma 391 analogues (Gardner et al. 2000; Larsen and Gardner 2000; Mangan and Sisson 2000; Gardner 2007; 392 Takeuchi et al. 2009; Shea et al. 2010; Okumura et al. 2012; Martel and Iacono-Marziano 2015; 393 Oppenheimer et al. 2015; Preuss et al. 2016; Colombier et al. 2020). Data is tallied in crystal-poor $(<10$ 394 vol\%), moderately crystal-rich (10-40 vol\%), and crystal-rich (>50 vol\%) categories, as well as whether 395 samples underwent closed-system degassing, or bore connected bubbles networks able to outgas. Figure 7 396 suggests that experimental magma outgassing has only been explored in low-pressure, shallow conditions, 397 which contrasts with our deep-seated determination of channelling during magma ascent. This compilation 398 also confirms that high crystal contents promote outgassing at low percolation thresholds.

400 The conditions leading to channelling are based on several key assumptions (Parmigiani et al. 2017; 401 Degruyter et al. 2019), the validity of which must be assessed in the case of conduit flow. One is that 
402 capillary forces dominates buoyancy forces so that the Bond number is $0.1-1$. The Bond number depends on 403 gravity, the density difference between melt and gas, the surface tension, and the radius of the gas bubbles. A 404 reasonable estimate for the melt density of the three studied volcanoes is $2300 \mathrm{~kg} / \mathrm{m}^{3}$. According to 405 Lyakhovsky et al. (1996), surface tension can be taken as $0.05 \mathrm{~N} / \mathrm{m}$. The most variable quantity is bubble size 406 because it depends highly on the pressure and bubble number density. A Bond number between 0.1 and 1 407 implies a bubble radius between 0.2 and $0.8 \mathrm{~mm}$. At depth, bubbles that size and smaller were likely, and the 408 assumption of dominating capillary forces holds. The possibility that bubbles adhere to crystal surfaces was 409 also left aside. This is a reasonable assumption in conduit conditions because microlites are mostly composed 410 of non-wetting phases like plagioclase in arc magmas. We note, however, that wetting phases like Fe-Mg 411 silicates or Fe-Ti oxides are also present, which suggests that investigating how crystal adherence affects 412 bubble channelling is a worthy pursuit.

414 Two other assumptions of Parmigiani et al. (2017) and Degruyter et al. (2019) are that the ambient pressure 415 is hydrostatic and that the crystal framework remains static during the onset of channelling. The lower 416 crystallinity limit of 40 vol\% stems from the assumption that crystalline matrix resists frictional sliding, 417 which corresponds to a random loose packing. Their synthetic crystal size and shape distributions aim to 418 represent a scaled version of phenocrysts prevailing in storage conditions. Microlite crystallization during 419 ascent yielded in our three studied cases linear to concave-up crystal size distributions with a significant 420 proportion of highly elongated microlites. Random loose packing and frictional effects in such distributions 421 occur at volume fraction lower than 40 vol\%, possibility as low as 8 vol\% (Saar et al. 2001; Guo et al. 2013). 422 The bubble coalescence leading to channelling, however, is controlled by how much interstitial space occurs 423 between crystals, which is inversely proportional to the cubic root of crystal volume fraction. It is thus 424 unlikely that the onset of channelling occurs at crystallinities much lower than that proposed by Parmigiani 425 et al. (2017), depending on crystal shapes and sizes. Similarly, the transition from channelling to bubble 426 trapping could also occur at a different (yet probably close to) volume fraction than the $70 \mathrm{vol} \%$ determined 427 numerically. 
429 Bubble trapping assumes a static solid matrix. It is no longer static when either local overpressure occurs, or 430 a far-field stress is applied to the medium, which are two likely processes in ascending magmas. Different 431 regimes of matrix deformation by local gas overpressure exist. Analogue experiments (Holtzman et al. 2012; 432 Oppenheimer et al. 2015) show that a regime of slow solid matrix rearrangement occurs at the random loose 433 packing, when gas bubbles begin to deform. This change is insensitive to liquid viscosity in the range 10$4341000 \mathrm{~Pa}$ s. Another regime of rapid deformation of the immersed granular medium by gas-induced 435 overpressure has been described as "venting" (Varas et al. 2015) or "capillary fracturing" (Holtzman et al. 436 2012). It occurs near the random close packing (Oppenheimer et al. 2015), and it is characterized by gas 437 migration in a fracture-like manner. These regimes have recently been proposed to play a role in Strombolian 438 dynamics when gas proportions are large and melt viscosities low ( $<5 \mathrm{~Pa} \mathrm{~s}$; Barth et al. 2019; Oppenheimer 439 et al. 2020). It is unclear yet probable that outgassing by channelling leads to limited grain displacement in 440 melts of much higher viscosity. The two values of crystal content framing channelling are thus reasonable 441 estimates that will be refined when reproduced experimentally with the assumption of static solid matrix 442 relaxed. As the same reasoning holds for the critical porosity (Eq. (3)), the shaded regions in Fig. 3b, 4b, and $4435 \mathrm{~b}$ indicate the two extreme values ever reached by numerical simulations of channelling (Degruyter et al. 444 2019). Considering only these extreme values does not change the conclusion that conditions for channelling 445 were met in the three studied cases.

447 Once channelling is established, gas evacuation can proceed to the point of fracture healing if large-scale 448 stresses are applied (Caricchi et al. 2011; Laumonier et al. 2011; Heap et al. 2015). Such gas expulsion is 449 thus expected in a crystal-rich magma sheared along a volcanic conduit (e.g., Thomas et al. 2019). Provided 450 that Eq. (3) is accurate, this is the most probable explanation of the porosities close to but lower than the 451 critical porosity at Soufrière Hills and Merapi (Figs. $3 \mathrm{~b}$ and $4 \mathrm{~b}$ ). We reiterate that channelling in deforming 452 suspension remains to be quantified to add weight to our inferences.

454 At Tungurahua, conditions for channelling were met between $110 \mathrm{MPa}$ and a gas-rich region located at 1-10 $455 \mathrm{MPa}$. Outgassing, however, could have happened through other mechanisms such as viscous percolation in 456 the main part of the conduit owing to the low melt viscosity $\left(10^{3.7} \mathrm{~Pa} s\right.$ at the reservoir level, Chevrel et al. 
457 2015), or brittle-viscous coalescence shallowly, where much higher melt viscosities are expected. Figure 6 458 shows closed-system degassing paths for three starting points: at $200 \mathrm{MPa}$ (reservoir level, Andújar et al. 459 2017), at $108 \mathrm{MPa}$, and at $34 \mathrm{MPa}$. These intermediate pressures correspond to the samples closest to the 460 points where total crystal contents reach and exceed the lower bound for channelling, respectively. The 461 decompression starting at $108 \mathrm{MPa}$ overestimates shallower porosities, whereas that starting at $34 \mathrm{MPa}$ 462 closely follows the trend of the most porous samples. That the measured shallow porosities can be explained 463 by decompressing the residual porosity around $40 \mathrm{MPa}$ suggests that gas loss by channelling was enabled by 464 microlite crystallization between 100 and $40 \mathrm{MPa}$ (1.6-2.9 km depth). The gas-rich region at 1-10 MPa (40$465400 \mathrm{~m}$ depth) could be due to the ascent of material immediately below that was fast enough to minimize 466 outgassing, or to gas accumulation. Accumulation implies that outgassing was inefficient close to the surface. 467 This could be caused by a combination of hindered channelling at high crystal content, hindered brittle468 viscous coalescence because of insufficient gas overpressure, and impermeable plug and conduit walls. Gas 469 accumulation is supported by the near-surface observation that measured porosities decrease to very low 470 values $(<1$ vol\%), revealing the presence of a low permeability, rigid plug (Gaunt et al. 2020). Since the 471 amount of crystals is very high in this plug, cracks or bubble connections (e.g., Heap et al. 2014) were not 472 efficient enough to evacuate the residual gas, thereby allowing the gas-rich region to form.

474 Our results suggest that outgassing by channelling could have occurred down to (and probably deeper than) $4752.7 \mathrm{~km}$ at Soufrière Hills, shallower than $3 \mathrm{~km}$ depth at Merapi, and between 1.5 and $3 \mathrm{~km}$ at Tungurahua. 476 One implication of such widespread channelling depths is that, besides rapidly changing magma rheology to 477 possibly trigger more explosive eruptions (Arzilli et al. 2019), microlite could also spur gas escape. Another 478 implication is that outgassing by channelling could occur regardless of near-surface conditions such as the 479 presence of a dome, a plug, or a permeable wallrock. Finally, the permeabilities reached by channelling are 480 high for magmas in general, and several orders of magnitude higher than commonly admitted permeabilities 481 at low porosity (e.g., Farquharson et al. 2015; Kushnir et al. 2016). Such high permeabilities would affect 482 transitions in eruptive style (Cassidy et al. 2018), and the corresponding permeability relationships given by 483 Parmigiani et al. (2017) and Degruyter et al. (2019) can readily be tested in conduit flow models. 


\section{Conclusions}

485 We revisited three reconstructions of porosity and crystal distributions prior to Vulcanian events that 486 occurred respectively on February 10, 2010 at Soufrière Hills volcano, Montserrat (Burgisser et al. 2019), on 487 October 26, 2010 at Merapi volcano, Indonesia (Drignon et al. 2016) and on July 14, 2013 at Tungurahua 488 volcano, Ecuador (Gaunt et al. 2020). They all feature porosities too low to be explained by common shallow 489 processes such as connected bubble pathways or cracks. Our data show that these magmas have high enough 490 crystal contents for outgassing to occur by a process named channelling. When the amount of crystals in a 491 three-phase magma lies within the $40-70$ vol\% range, the interstitial space is narrow enough to force bubbles 492 to form channels in which the gas buoyantly moves upwards but not so constricted that channel connections 493 are ruptured (Parmigiani et al. 2017). Channelling creates gas permeability of the order of $10^{-10} \mathrm{~m}^{2}$, which is 494 two to five orders of magnitude higher than the other permeability processes at the equivalent bubble 495 content.

497 At Soufrière Hills, microlite crystallization during ascent yielded conditions propitious to channelling from 498 near surface down to a depth greater than $2.7 \mathrm{~km}$. If confidence is given in the critical porosity 499 quantification, outgassing deflated the magma slightly below the critical porosity, which suggests that large500 scale stresses such as those related to conduit wall shearing were also at play in controlling the evolution of 501 porosity during ascent.

502

503 At Merapi, the phenocrysts in the reservoirs could have fostered outgassing at depth without magma ascent.

504 Closed-system degassing in response to ascent, however, only yielded enough gas for channelling at mid505 conduit depths. The part of the conduit where both gas contents were large enough and calculated porosities 506 fall within the percolation range is located around $3 \mathrm{~km}$ depth. In this region and in the shallower parts of the 507 conduit, outgassing by channelling could have taken place during (and possibly before) microlite 508 crystallization but before the $70 \%$ crystal content was reached. This suggests that the strong gas depletion in 509 the magma column could have resulted from weak exsolution at the beginning of the ascent followed by 510 channelling at depths shallower than $3 \mathrm{~km}$. Of the two end-member magmas involved in the eruption that we 
511 considered in our analysis, this degassing behaviour is best explained if the conduit was filled by the colder 512 resident magma.

\section{3}

514 At Tungurahua, outgassing by channelling was enabled by microlite crystallization at $1.6-2.9 \mathrm{~km}$ depth.

515 Near the surface, a low permeability plug trapped a gas-rich region between 40 and $400 \mathrm{~m}$ depth. Inefficient

516 outgassing between $1.6 \mathrm{~km}$ and the gas accumulation region was probably caused by a combination of

517 hindered channelling at high crystal content, hindered brittle-viscous coalescence because of insufficient gas

518 overpressure, and impermeable plug and conduit walls. This suggests that the triggering of the paroxysmal

519 explosion was controlled by near-surface gas trapping.

521 We presented lines of evidence for deep gas loss prior to sudden explosive emissions of three basaltic

522 andesitic to andesitic magmas. They suggest that channelling is a viable mechanism for gas to be removed

523 from the magma column at various levels during ascent, yielding mostly gas-depleted magma columns prior 524 to eruption. Such outgassing by channelling could thus influence eruptive style. Depending on the 525 phenocryst content, microlite growth during ascent can either foster, or impede gas escape by channelling. 526 Considering the pervasive occurrence of microlites and ensuing high crystal contents in volcanic conduits, 527 the high likelihood of outgassing by channelling implies that other outgassing mechanisms might not be as 528 dominant as previously envisioned. 


\section{Tables}

531 Table 1: Pre-explosive volatile proportions, vesicle-free crystal proportions, and pressures. Values in

532 parenthesis are relative uncertainties in \% except for the pressure, where they indicate lower and upper

533 bounds of uncertainties in MPa. Uncertainties on phenocryst content are sometimes very low $(<1 \%)$, which

534 reflects that few SEM images were imaged to characterize phenocrysts. Uncertainties on the total crystal

535 fraction include those due to microlite, which are obtained from a larger number of images. They thus reflect

536 more accurately the natural spatial variability.

\begin{tabular}{|c|c|c|c|c|c|}
\hline & $\begin{array}{c}\text { Pressure } \\
(\mathrm{MPa})\end{array}$ & $\begin{array}{l}\text { Porosity }^{a} \\
\text { (vol\%) }\end{array}$ & $\begin{array}{c}\text { Gas }^{\mathrm{b}} \\
\text { (ppmw) }\end{array}$ & $\begin{array}{c}\text { Phenocrysts } \\
\text { (vol\%) }\end{array}$ & $\begin{array}{l}\text { Crystals } \\
\text { (vol\%) }\end{array}$ \\
\hline \multicolumn{6}{|c|}{ Soufrière Hills } \\
\hline AMO $210 \mathrm{~A}$ & $40(-9,+10)$ & $1.9(1)$ & 0.6 & $34(2)$ & $54(10)$ \\
\hline AMO $210 \mathrm{C}$ & $51(-25,+31)$ & $2.3(2)$ & 0.92 & $34(12)$ & $55(22)$ \\
\hline AMO $210 \mathrm{D}$ & $14(-3,+3)$ & $1.9(1)$ & 0.2 & $31(6)$ & $39(11)$ \\
\hline AMO $210 \mathrm{E}$ & $54(-19,+22)$ & $3.5(0)$ & 1.54 & $48(0.3)$ & $69(9)$ \\
\hline AMO $210 \mathrm{~F}$ & $33(-8,+9)$ & $1.6(1)$ & 0.41 & $50(2)$ & $66(13)$ \\
\hline AMO $210 \mathrm{G}$ & $42(-13,+15)$ & $1.2(3)$ & 0.39 & $40(12)$ & $63(11)$ \\
\hline AMO $210 \mathrm{H}$ & $12(-5,+6)$ & $8.5(1)$ & 0.89 & $39(8)$ & $65(12)$ \\
\hline AMO $210 \mathrm{~L}$ & $46(-13,+14)$ & $1.4(2)$ & 0.52 & $59(3)$ & $77(6)$ \\
\hline AMO $210 Q$ & $41(-7,+7)$ & $3.4(1)$ & 1.14 & $32(1.3)$ & $40(14)$ \\
\hline WP1.095A & $24(-5,+5)$ & $4.3(0)$ & 0.86 & $24(0.4)$ & $52(3)$ \\
\hline WP1.095B & $16(-6,+7)$ & $7.2(0)$ & 0.95 & $32(0.2)$ & 59 (9) \\
\hline WP1.108A & $31(-5,+5)$ & $2.8(0)$ & 0.72 & $32(0.3)$ & $52(10)$ \\
\hline WP1.108B & $56(-5,+5)$ & $7.8(1)$ & 3.68 & $36(1.1)$ & $48(3)$ \\
\hline WP2.200A & $36(-8,+9)$ & $2.8(0)$ & 0.81 & $42(0.3)$ & $63(19)$ \\
\hline WP2.200B & $31(-2,+2)$ & $3(0)$ & 0.76 & $31(0.7)$ & $42(3)$ \\
\hline WP2.201A & $35(-8,+9)$ & $4.6(0)$ & 1.33 & $45(0.2)$ & $59(10)$ \\
\hline WP2.201B & $69(-14,+15)$ & $2.4(0)$ & 1.36 & $31(0.2)$ & $51(8)$ \\
\hline WP2.329A & $7(-1,+1)$ & $23.6(0)$ & 1.62 & $11(1.2)$ & $27(15)$ \\
\hline WP2.329B & $41(-4,+4)$ & $2.7(1)$ & 0.89 & $51(2)$ & $65(3)$ \\
\hline \multicolumn{6}{|c|}{ Merapi Oct. 26} \\
\hline AME 10 A1 & $75(-22,+25)$ & $2.3(4)$ & 1.27 & $33(7)$ & $70(11)$ \\
\hline AME 10 A2 & $100(-34,+38)$ & $1.5(4)$ & 1.12 & $44(8)$ & $79(8)$ \\
\hline AME 10 A3 & $150(-123,+174)$ & $1.2(3)$ & 1.32 & $40(3)$ & $82(11)$ \\
\hline AME 10 A4 & $100(-22,+24)$ & $1.6(5)$ & 1.16 & $45(8)$ & $80(8)$ \\
\hline AME 10 A5 & $73(-25,+29)$ & $2.4(3)$ & 1.32 & $47(5)$ & $76(6)$ \\
\hline AME 10 A6 & $58(-12,+13)$ & $3.1(2)$ & 1.32 & $46(3)$ & $72(5)$ \\
\hline AME 10 B1 & $158(-48,+53)$ & $0.9(4)$ & 1.03 & $41(9)$ & $80(10)$ \\
\hline AME 10 B2 & $63(-11,+12)$ & $2.3(3)$ & 1.05 & $50(5)$ & $72(8)$ \\
\hline AME 10 B4 & $268(-106,+118)$ & $0.6(4)$ & 1.14 & $36(6)$ & $87(6)$ \\
\hline
\end{tabular}




\begin{tabular}{|c|c|c|c|c|c|}
\hline AME 10 B5 & $260(-153,+184)$ & $0.4(5)$ & 0.73 & $44(13)$ & $87(12)$ \\
\hline AME $10 \mathrm{C} 1$ & $159(-57,+64)$ & $1(1)$ & 1.13 & $38(1)$ & 80 (14) \\
\hline AME 10 C2 & $141(-31,+33)$ & $0.7(2)$ & 0.69 & $38(5)$ & $81(6)$ \\
\hline AME 10 C3 & $55(-17,+20)$ & $2.8(2)$ & 1.16 & $46(3)$ & $70(10)$ \\
\hline AME 10 C4 & $77(-24,+27)$ & $1.4(3)$ & 0.78 & $44(7)$ & $77(7)$ \\
\hline AME 10 D1 & $107(-25,+27)$ & $1.1(3)$ & 0.88 & $44(4)$ & $79(9)$ \\
\hline AME 10 D2 & $85(-37,+43)$ & $1.4(5)$ & 0.88 & $42(11)$ & $79(11)$ \\
\hline AME 10 D3 & $64(-37,+47)$ & $2(8)$ & 0.96 & $34(20)$ & $69(27)$ \\
\hline AME 10 D4 & $63(-14,+15)$ & $2.8(5)$ & 1.34 & $42(12)$ & $71(10)$ \\
\hline AME 10 E1 & $75(-23,+26)$ & $1.2(2)$ & 0.67 & $42(6)$ & $74(11)$ \\
\hline AME 10 E2 & $202(-67,+74)$ & $0.9(4)$ & 1.26 & $57(4)$ & $88(4)$ \\
\hline AME 10 E3 & $59(-11,+12)$ & $2(3)$ & 0.86 & $43(9)$ & $74(8)$ \\
\hline AME 10 E4 & $77(-15,+16)$ & $1.9(5)$ & 1.1 & $45(10)$ & $72(8)$ \\
\hline AME 10 E5 & $227(-78,+87)$ & $0.5(4)$ & 0.85 & $45(12)$ & $86(11)$ \\
\hline AME 10 F1 & $12(-5,+5)$ & $2.3(20)$ & 0.2 & $21(23)$ & $54(17)$ \\
\hline AME 10 G1 & $42(-16,+18)$ & $2.3(2)$ & 0.76 & $52(5)$ & $75(7)$ \\
\hline AME 10 G2 & $75(-54,+75)$ & $1.1(2)$ & 0.78 & $51(6)$ & $82(11)$ \\
\hline AME 10 G3 & $44(-21,+25)$ & $0.3(15)$ & 0.48 & $41(9)$ & $70(12)$ \\
\hline AME $10 \mathrm{GA}$ & $94(-25,+28)$ & $2.8(1)$ & 0.89 & $48(10)$ & $81(9)$ \\
\hline AME $10 \mathrm{~GB}$ & $196(-80,+92)$ & $1.6(1)$ & 0.86 & $47(8)$ & $88(8)$ \\
\hline \multicolumn{6}{|l|}{ Tungurahua } \\
\hline 1 & $0.8(-0.2,+0.4)$ & $36.8(3)$ & 0.33 & $15(21)$ & $55(12)$ \\
\hline 2 & $0.5(-0.1,+0.1)$ & $0(8)$ & 0 & $46(10)$ & $73(9)$ \\
\hline 4 & $0.9(-0.2,+0.3)$ & $0.9(11)$ & 0.01 & $42(14)$ & $67(13)$ \\
\hline 6 & $0.5(-0.1,+0.2)$ & $0.3(30)$ & 0.001 & $39(36)$ & $70(32)$ \\
\hline 7.5 & $0.6(-0.2,+0.3)$ & $0.8(9)$ & 0.004 & $30(12)$ & $62(12)$ \\
\hline 11 & $3(-1,+1)$ & $0(1)$ & 0 & $25(1.4)$ & $44(5)$ \\
\hline 12 & $109(-63,+91)$ & $0.3(1)$ & 0.24 & $34(0.8)$ & $38(5)$ \\
\hline 13 & $5(-2,+9)$ & $44.2(1)$ & 2.53 & $32(2)$ & $48(14)$ \\
\hline 14 & $31(-17,+68)$ & $8.5(4)$ & 2.07 & $38(4)$ & $45(6)$ \\
\hline 16 & $1.6(-0.4,+0.5)$ & $15.7(4)$ & 0.21 & $31(3)$ & $55(5)$ \\
\hline 17 & $24(-8,+16)$ & $1.7(2)$ & 0.29 & $36(6)$ & $43(6)$ \\
\hline 18 & $34(-15,+41)$ & $6.1(1)$ & 1.57 & $34(2)$ & $43(6)$ \\
\hline 20 & $66(-14,+20)$ & $1.5(2)$ & 0.69 & $31(3)$ & $36(4)$ \\
\hline 21 & $5(-3,+8)$ & $3.2(2)$ & 0.12 & $36(3)$ & $51(10)$ \\
\hline 22 & $2(-1,+5)$ & $0(4)$ & 0 & $26(3)$ & $48(15)$ \\
\hline 26 & $51(-36,+149)$ & $8(3)$ & 3.14 & $32(2)$ & $39(9)$ \\
\hline 27 & $15(-5,+10)$ & $8.5(3)$ & 1.01 & $34(5)$ & $42(8)$ \\
\hline 28 & $5(-2,+9)$ & $36.5(3)$ & 1.86 & $29(6)$ & 45 (12) \\
\hline 29 & $30(-17,+82)$ & $7.7(1)$ & 1.77 & $30(0.8)$ & $36(6)$ \\
\hline 30 & $4(-1,+2)$ & $51.7(1)$ & 3.14 & $23(4)$ & $41(8)$ \\
\hline 34 & $1.2(-0.3,+0.4)$ & $45(3)$ & 0.69 & $25(2)$ & $53(6)$ \\
\hline 35 & $4(-1,+2)$ & $11.5(3)$ & 0.4 & $28(3)$ & $46(5)$ \\
\hline 36 & $5(-1,+2)$ & $8.1(1)$ & 0.33 & $30(2)$ & $47(7)$ \\
\hline 38 & $31(-14,+38)$ & $10.6(1)$ & 2.62 & $39(2)$ & $45(4)$ \\
\hline
\end{tabular}




\begin{tabular}{llllll}
\hline 39 & $31(-17,+67)$ & $1.5(2)$ & 0.33 & $34(5)$ & $40(7)$ \\
\hline 40 & $10(-0.1,+0.1)$ & $25.7(2)$ & 2.43 & $38(2)$ & $49(2)$ \\
\hline 41 & $174(-79,+26)$ & $0.3(2)$ & 0.4 & $26(3)$ & $32(4)$ \\
\hline
\end{tabular}

\section{Figure captions}

540 Fig.1: Porosity as a function of pre-explosive pressure for the February 10, 2010 Vulcanian explosion at 541 Soufrière Hills. Data are from Burgisser et al. (2019) and the «equilibrium» curve corresponds to 542 closed-system degassing. Other curves are from the open-system degassing conduit flow models of 543 Clarke et al. (2007), Melnik and Sparks (2002), the MAMMA code (La Spina et al. 2017; Degruyter et 544 al. 2012), and Collombet (2009)

545 Fig. 2: Schematic depiction of the textural elements considered. Clasts represent the magma in "Quench 546 state", which is composed of melt (blue), crystals (red), and vesicles (white). Vesicles are preexplosive (Type 1), syn-explosive and isolated (Type 2), syn-explosive gaps between broken crystals (Type 3), and syn-explosive and coalesced (Type 4). Prior to ejection, the magma is in a "Preexplosive state". It is composed of Type 1 vesicles that occupy a smaller volume than in the quench state because they are stored a high pressure in the conduit. The "ascent from the reservoir" allows the magma to reach the pre-explosive state in the conduit. If the critical porosity $\left(\phi_{c r}\right)$ is reached during ascent, channelling could cause vesicles to form channels that enable outgassing. The far-right panel is a visual depiction of the definitions of porosity, $\phi$, vesicle-free crystal volume fraction, $\phi_{x v}$, and bulk crystal volume fraction, $\phi_{x}$

Fig. S2: Pre-explosive porosities and associated model uncertainties of this study (Table 1) and those of Burgisser et al. (2019) (A), Gaunt et al. (2020) (B), and Drignon et al. (2016) (C)

Fig.3: a) Amount of phenocrysts (red) and phenocrysts plus microliths (blue) relative to pressure for Soufrière Hills according to Burgisser et al. (2019). The shaded region covers the validity domain for the development of channelling according to Parmigiani et al. (2017). b) Porosity thresholds calculated from Degruyter et al. (2019) and associated uncertainties (blue) for Soufrière Hills. Samples with crystal contents outside the validity range were discarded. Red dots are observed porosities. The 
associated uncertainties are smaller than the symbols. The green line gives theoretical porosities for a closed system. The shaded region covers the extreme porosity threshold values

564 Fig.4: a) Contents of phenocrysts (red) and phenocrysts plus microlite (blue) as a function of pressure for Merapi according to Drignon et al. (2016). The shaded region covers the validity domain for the development of channelling according to Parmigiani et al. (2017). b) Porosity thresholds calculated from Degruyter et al. (2019) and associated uncertainties (blue) for Merapi. Red dots are observed

Fig.5: a) Contents of phenocrysts (red) and phenocrysts plus microlites (blue) as a function of pressure for porosities and the associated uncertainties are smaller than the symbols. Green and black lines give theoretical porosities for a closed system with $5 \mathrm{wt} \% \mathrm{H}_{2} \mathrm{O}$ and $400 \mathrm{ppm} \mathrm{CO}_{2}$ in the melt (resident magma) and with $3 \mathrm{wt} \% \mathrm{H}_{2} \mathrm{O}$ and $500 \mathrm{ppm} \mathrm{CO}_{2}$ in the melt (recharge magma) respectively. The shaded region covers the extreme porosity threshold values

Fig.6: Comparison at Tungurahua between pre-eruptive porosities (red circles), and theoretical porosities for closed systems starting decompressing at the reservoir level of $200 \mathrm{MPa}$ (green line), at $108 \mathrm{MPa}$ (cyan line), and at $34 \mathrm{MPa}$ (magenta line) Tungurahua according to Gaunt et al. (2020). The shaded region covers the validity domain for the development of channelling according to Parmigiani et al. (2017). b) Porosity thresholds calculated from Degruyter et al. (2019) and associated uncertainties (blue) for Tungurahua. Samples with crystal contents outside the validity range were discarded. Red dots are observed porosities and the associated uncertainties are smaller than the symbols. Green line gives the theoretical porosities for a closed system. The shaded region covers the extreme porosity threshold values

Fig.7: Porosity profile as a function of depth for vesiculation experiments on crystal-free to crystal-rich magmas and magma analogues. The coloured areas respectively overlap samples with connected bubbles networks capable of outgassing. All other samples featured closed system degassing. Data are from Gardner et al. (2000), Larsen and Gardner (2000), Mangan and Sisson (2000), Gardner (2007); Takeuchi et al. (2009), Shea et al. (2010), Okumura et al. (2012), Martel and Iacono-Marziano (2015), Oppenheimer et al. (2015), Preuss et al. (2016), and Colombier et al. (2020) 
589 


\section{References}

Andújar J, Martel C, Pichavant M, Samaniego P, Scaillet B, Molina I (2017) Structure of the Plumbing System at Tungurahua Volcano, Ecuador: Insights from Phase Equilibrium Experiments on July-August 2006 Eruption Products. J Petrol 58, 1249-1278. https://doi.org/10.1093/petrology/egx054

Arzilli F, La Spina G, Burton MR, Polacci M, Le Gall N, Hartley ME, Di Genova D, Cai B, Vo NT, Bamber EC, Nonni S, Atwood R, Llewellin EW, Brooker RA, Mader HM, Lee PD (2019) Magma fragmentation in highly explosive basaltic eruptions induced by rapid crystallization. Nat Geosci 12, 1023-1028. https://doi.org/10.1038/s41561-019. 0468-6

Barth A, Edmonds M, Woods A (2019) Valve-like dynamics of gas flow through a packed crystal mush and cyclic strombolian explosions. Sci Rep 9, 821. https://doi.org/10.1038/s41598-018-37013-8

Battaglia, J., Hidalgo, S., Bernard, B., Steele, A., Arellano, S., Acuña, K., 2019. Autopsy of an eruptive phase of Tungurahua volcano (Ecuador) through coupling of seismo-acoustic and $\mathrm{SO} 2$ recordings with ash characteristics. Earth and Planetary Science Letters 511, 223-232. https://doi.org/10.1016/j.epsl.2019.01.042

Blower, J. B (2001) Factors controlling permeability-porosity relationships in magma. Bulletin of Volcanology 63:497504. https://doi.org/10.1007/s004450100172

Budi-Santoso A, Lesage P, Dwiyono S, Sumarti S, Subandriyo, Surono, Jousset P, Metaxian JP (2013) Analysis of the seismic activity associated with the 2010 eruption of Merapi Volcano, Java. J Volcanol Geotherm Res 261, $153-170$. https://doi.org/10.1016/j.jvolgeores.2013.03.024

Burgisser A, Alletti M, Scaillet B (2015) Simulating the behavior of volatiles belonging to the C-O-H-S system in silicate melts under magmatic conditions with the software D-Compress. Comput Geosci 79, 1-14.

Burgisser A, Bechon T, Chevalier L, Collombet M, Arbaret L, Forien M (2019) Conduit processes during the February 11, 2010 Vulcanian eruption of Soufrière Hills, Montserrat. J Volcanol Geotherm Res 373, 23-35.

https://doi.org/10.1016/j.jvolgeores.2019.01.020

Burgisser A, Chevalier L, Gardner JE, Castro JM (2017) The percolation threshold and permeability evolution of ascending magmas. Earth Planet Sci Lett 470, 37-47. https://doi.org/10.1016/j.epsl.2017.04.023

Burgisser A, Poussineau S, Arbaret L, Druitt TH, Giachetti T, Bourdier JL (2010) Pre-explosive conduit conditions of the 1997 Vulcanian explosions at Soufrière Hills Volcano, Montserrat: I. Pressure and vesicularity distributions. J Volcanol Geotherm Res 194, 27-41. https://doi.org/10.1016/j.jvolgeores.2010.04.008

Cardosso SSS, Woods AW, 1999. On convection in a volatile-saturated magma. Earth Planet Sci Lett 168, $301-310$. https://doi.org/10.1016/S0012-821X(99)00057-6

Caricchi L, Pommier A, Pistone M, Castro J, Burgisser A, Perugini D (2011) Strain-induced magma degassing: insights from simple-shear experiments on bubble bearing melts. Bull Volcanol 73, 1245-1257. https://doi.org/10.1007/s00445011-0471-2

Cassidy M, Manga M, Cashman K, Bachmann O (2018) Controls on explosive-effusive volcanic eruption styles. Nat Commun 9, 2839. https://doi.org/10.1038/s41467-018-05293-3

Chevrel MO, Cimarelli C, deBiasi L, Hanson JB, Lavallée Y, Arzilli F, Dingwell DB (2015) Viscosity measurements of crystallizing andesite from Tungurahua volcano (Ecuador). Geochem Geophys Geosystems G3 16, 870-889.

https://doi.org/10.1002/2014GC005661

Clarke AB, Stephens S, Teasdale R, Sparks RSJ, Diller K (2007) Petrologic constraints on the decompression history of magma prior to Vulcanian explosions at the Soufrière Hills volcano, Montserrat. J Volcanol Geotherm Res 161, 261 274. https://doi.org/10.1016/j.jvolgeores.2006.11.007

Collombet M (2009) Two-dimensional gas loss for silicic magma flows: toward more realistic numerical models. Geophys J Int 177, 309-318. https://doi.org/10.1111/j.1365-246X.2008.04086.x

Colombier M, Wadsworth FB, Scheu B, Vasseur J, Dobson KJ, Cáceres F, Allabar A, Marone F, Schlepütz CM, Dingwell DB (2020) In situ observation of the percolation threshold in multiphase magma analogues. Bull Volcanol 82 , 32. https://doi.org/10.1007/s00445-020-1370-1

Costa F, Andreastuti S, Bouvet de Maisonneuve C, Pallister JS (2013) Petrological insights into the storage conditions, and magmatic processes that yielded the centennial 2010 Merapi explosive eruption. J Volcanol Geotherm Res 261, 209-235. https://doi.org/10.1016/j.jvolgeores.2012.12.025

Couch S, Sparks RSJ, Carroll MR (2003) The kinetics of degassing-induced crystallization at Soufrière Hills volcano, Montserrat. Journal of Petrology 44:1477-1502

deGraffenried RL, Larsen JF, Graham NA, Cashman KV (2019) The influence of phenocrysts on degassing in crystalbearing magmas with rhyolitic groundmass melts. Geophysical Research Letters 46:5127-5136.

https://doi.org/10.1029/2018GL081822 
Degruyter W, Bachmann O, Burgisser A, Manga M (2012) The effects of outgassing on the transition between effusive and explosive silicic eruptions. Earth Planet Sci Lett 349-350, 161-170. https://doi.org/10.1016/j.epsl.2012.06.056

Degruyter W, Parmigiani A, Huber C, Bachmann O (2019) How do volatiles escape their shallow magmatic hearth? Philos Trans R Soc Lond Ser A 377, 20180017. https://doi.org/10.1098/rsta.2018.0017

Drignon MJ, Bechon T, Arbaret L, Burgisser A, Komorowski JC, Caroline M, Hayden M, Yaputra R (2016)

Preexplosive conduit conditions during the 2010 eruption of Merapi volcano (Java, Indonesia). Geophys Res Lett 43 , 11,595-11,602. https://doi.org/10.1002/2016GL071153

Edmonds M, Aiuppa A, Humphreys M, Moretti R, Giudice G, Martin RS, Herd RA, Christopher T (2010) Excess volatiles supplied by mingling of mafic magma at an andesite arc volcano. Geochem Geophys Geosystems 11, 4 . https://doi.org/10.1029/2009GC002781

Erdmann S, Martel C, Pichavant M, Bourdier JL, Champallier R, Komorowski JC, Cholik N (2016) Constraints from Phase Equilibrium Experiments on Pre-eruptive Storage Conditions in Mixed Magma Systems: a Case Study on Crystal-rich Basaltic Andesites from Mount Merapi, Indonesia. J Petrol 57, 535-560.

https://doi.org/10.1093/petrology/egw019

Eychenne, J., Le Pennec, J.-L., Troncoso, L., Gouhier, M., Nedelec, J.-M., 2012. Causes and consequences of bimodal grain-size distribution of tephra fall deposited during the August 2006 Tungurahua eruption (Ecuador). Bull Volcanol 74, 187-205. https://doi.org/10.1007/s00445-011-0517-5

Farquharson J, Heap MJ, Varley NR, Baud P, Reuschlé T (2015) Permeability and porosity relationships of edificeforming andesites: A combined field and laboratory study. J Volcanol Geotherm Res 297, 52-68.

https://doi.org/10.1016/j.jvolgeores.2015.03.016

Gardner JE (2007) Bubble coalescence in rhyolitic melts during decompression from high pressure. J Volcanol Geotherm Res. 166, 161-176. https://doi.org/10.1016/j.jvolgeores.2007.07.006

Gardner JE, Hilton M, Carroll MR (2000) Bubble growth in highly viscous silicate melts during continuous decompression from high pressure. Geochim Cosmochim Acta 64, 1473-1483. https://doi.org/10.1016/S00167037(99)00436-6

Gaunt HE, Burgisser A, Mothes PA, Browning J, Meredith PG, Criollo E, Bernard B (2020) Triggering of the powerful 14 July 2013 Vulcanian explosion at Tungurahua Volcano, Ecuador. J Volcanol Geotherm Res 392, 106762.

https://doi.org/10.1016/j.jvolgeores.2019.106762

Giachetti T, Druitt TH, Burgisser A, Arbaret L, Galven C (2010) Bubble nucleation, growth and coalescence during the 1997 Vulcanian explosions of Soufrière Hills Volcano, Montserrat. J Volcanol Geotherm Res 193, $215-231$.

https://doi.org/10.1016/j.jvolgeores.2010.04.001

Gonnermann HM, Giachetti T, Fliedner C, Nguyen CT, Houghton BF, Crozier JA, Carey RJ (2017) Permeability

During Magma Expansion and Compaction. J Geophys Res Solid Earth 122, 9825-9848.

https://doi.org/10.1002/2017JB014783

Guo Y, Wassgren C, Hancock B, Ketterhagen W, Curtis J (2013) Granular shear flows of flat disks and elongated rods without and with friction. Phys Fluids 25, 063304. https://doi.org/10.1063/1.4812386

Hall, M.L., Steele, A.L., Bernard, B., Mothes, P.A., Vallejo, S.X., Douillet, G.A., Ramón, P.A., Aguaiza, S.X., Ruiz, M.C., 2015. Sequential plug formation, disintegration by Vulcanian explosions, and the generation of granular Pyroclastic Density Currents at Tungurahua volcano (2013-2014), Ecuador. Journal of Volcanology and Geothermal Research 306, 90-103. https://doi.org/10.1016/j.jvolgeores.2015.09.009

Heap MJ, Farquharson JI, Baud P, Lavallée Y, Reuschlé T (2015) Fracture and compaction of andesite in a volcanic edifice. Bull Volcanol 77, 55. https://doi.org/10.1007/s00445-015-0938-7

Heap MJ, Lavallée Y, Petrakova L, Baud P, Reuschlé T, Varley NR, Dingwell DB (2014) Microstructural controls on the physical and mechanical properties of edifice-forming andesites at Volcán de Colima, Mexico. J Geophys Res Solid Earth 119, 2013JB010521. https://doi.org/10.1002/2013JB010521

Hidalgo, S., Battaglia, J., Arellano, S., Steele, A., Bernard, B., Bourquin, J., Galle, B., Arrais, S., Vásconez, F., 2015. $\mathrm{SO}_{2}$ degassing at Tungurahua volcano (Ecuador) between 2007 and 2013: Transition from continuous to episodic activity. Journal of Volcanology and Geothermal Research 298, 1-14. https://doi.org/10.1016/j.jvolgeores.2015.03.022

Higgins MD, Roberge J (2003) Crystal size distribution of plagioclase and amphibole from Soufrière Hills Volcano, Montserrat: Evidence for dynamic crystallization-textural coarsening cycles. Journal of Petrology 44:1401-1411

Holtzman R, Szulczewski ML, Juanes R (2012) Capillary Fracturing in Granular Media. Phys Rev Lett 108, 264504. https://doi.org/10.1103/PhysRevLett.108.264504

Klug C, Cashman KV (1996) Permeability development in vesiculating magmas: implications for fragmentation. Bull. Volcanol. 58, 87-100. https://doi.org/10.1007/s004450050128 
Kushnir ARL, Martel C, Bourdier JL, Heap MJ, Reuschlé T, Erdmann S, Komorowski JC, Cholik N (2016) Probing permeability and microstructure: Unravelling the role of a low-permeability dome on the explosivity of Merapi (Indonesia). J Volcanol Geotherm Res 316, 56-71. https://doi.org/10.1016/j.jvolgeores.2016.02.012

Kushnir ARL, Martel C, Champallier R, Arbaret L (2017) In situ confirmation of permeability development in shearing bubble-bearing melts and implications for volcanic outgassing. Earth and Planetary Science Letters 458:315-326. https://doi.org/10.1016/j.eps1.2016.10.053

La Spina G, de' Michieli Vitturi M, Clarke AB (2017) Transient numerical model of magma ascent dynamics: application to the explosive eruptions at the Soufrière Hills Volcano. J Volcanol Geotherm Res 336, 118-139. https://doi.org/10.1016/j.jvolgeores.2017.02.013

Larsen JF, Gardner JE (2000) Experimental constraints on bubble interactions in rhyolite melts: implications for vesicle size distribution. Earth Planet Sci Lett 180, 201-214. https://doi.org/10.1016/S0012-821X(00)00166-7

Laumonier M, Arbaret L, Burgisser A, Champallier R (2011) Porosity redistribution enhanced by strain localization in crystal-rich magmas. Geology 39, 715-718. https://doi.org/10.1130/G31803.1

Lindoo A, Larsen JF, Cashman KV, Oppenheimer J (2017) Crystal controls on permeability development and degassing in basaltic andesite magma. Geology 45, 831-834. https://doi.org/10.1130/G39157.1

Lyakhovsky V, Hurwitz S, Navon O (1996) Bubble growth in rhyolitic melts: experimental and numerical investigation. Bull. Volcanol. 58, 19-32. https://doi.org/10.1007/s004450050122

Mangan M, Sisson T (2000) Delayed, disequilibrium degassing in rhyolite magma: decompression experiments and implications for explosive volcanism. Earth Planet Sci Lett 183, 441-455. https://doi.org/10.1016/S0012821X(00)00299-5

Martel C, Iacono-Marziano G (2015) Timescales of bubble coalescence, outgassing, and foam collapse in decompressed rhyolitic melts. Earth Planet Sci Lett 412, 173-185. https://doi.org/10.1016/j.eps1.2014.12.010

Melnik O, Sparks RSJ (2002) Dynamics of magma ascent and lava extrusion at Soufrière Hills Volcano, Montserrat. Geol. Soc. Lond. Mem. 21, 153-171. https://doi.org/10.1144/GSL.MEM.2002.021.01.07

Michaut C, Bercovici D, Sparks RSJ (2009) Ascent and compaction of gas rich magma and the effects of hysteretic permeability. Earth Planet Sci Lett 282, 258-267. https://doi.org/10.1016/j.epsl.2009.03.026

Mueller S, Scheu B, Spieler O, Dingwell DB (2008) Permeability control on magma fragmentation. Geology 36, 399402. https://doi.org/10.1130/G24605A.1

Murch AP, Cole PD (2019) Using microlites to gain insights into ascent conditions of differing styles of volcanism at Soufrière Hills Volcano. Journal of Volcanology and Geothermal Research 384:221-231.

https://doi.org/10.1016/j.jvolgeores.2019.07.022

Nadeau O, Williams-Jones AE, Stix J (2013) Magmatic-hydrothermal evolution and devolatilization beneath Merapi volcano, Indonesia. J Volcanol Geotherm Res. 261, 50-68. https://doi.org/10.1016/j.jvolgeores.2013.04.006

Okumura S, Nakamura M, Nakano T, Uesugi K, Tsuchiyama A (2012) Experimental constraints on permeable gas transport in crystalline silicic magmas. Contrib Mineral Petrol 164, 493-501. https://doi.org/10.1007/s00410-012-07508

Oppenheimer C, Lomakina AS, Kyle PR, Kingsbury NG, Boichu M (2009) Pulsatory magma supply to a phonolite lava lake. Earth Planet Sci Lett 284, 392-398. https://doi.org/10.1016/j.epsl.2009.04.043

Oppenheimer J, Capponi A, Cashman KV, Lane SJ, Rust AC, James MR (2020) Analogue experiments on the rise of large bubbles through a solids-rich suspension: A "weak plug" model for Strombolian eruptions. Earth Planet Sci Lett 531, 115931. https://doi.org/10.1016/j.epsl.2019.115931

Oppenheimer J, Rust AC, Cashman KV, Sandnes B (2015) Gas migration regimes and outgassing in particle-rich suspensions. Front Phys 3. https://doi.org/10.3389/fphy.2015.00060

Parmigiani A, Faroughi S, Huber C,Bachmann 0, Su Y (2016) Bubble accumulation and its role in the evolution of magma reservoirs in the upper crust. Nature 532, 492-495. https://doi.org/10.1038/nature17401

Parmigiani A, Degruyter W, Leclaire S, Huber C, Bachmann O (2017) The mechanics of shallow magma reservoir outgassing. Geochem Geophys Geosystems 18, 2887-2905. https://doi.org/10.1002/2017GC006912

Preece K, Gertisser R, Barclay J, Berlo K, Herd RA, Edinburgh Ion Microprobe Facility (2014) Pre- and syn-eruptive degassing and crystallisation processes of the 2010 and 2006 eruptions of Merapi volcano, Indonesia. Contrib Mineral Petrol 168, 1061. https://doi.org/10.1007/s00410-014-1061-z

Preuss O, Marxer H, Ulmer S, Johannes W, Nowak M (2016) Special Collection: Rates and Depths of Magma Ascent on Earth: Degassing of Hydrous Trachytic Campi Flegrei and Phonolitic Vesuvius Melts: Experimental Limitations and Chances to Study Homogeneous Bubble Nucleation. Am Mineral 101, 859-875. https://doi.org/10.2138/am-2016-5480 Rust AC, Cashman KV (2004) Permeability of vesicular silicic magma: inertial and hysteresis effects. Earth Planet Sci Lett 228, 93-107. https://doi.org/10.1016/j.epsl.2004.09.025 
Saar MO, Manga M, Cashman KV, Fremouw S (2001) Numerical models of the onset of yield strength in crystal-melt suspensions. Earth Planet Sci Lett 187, 367-379. https://doi.org/10.1016/S0012-821X(01)00289-8

Samaniego P, Le Pennec J-L, Robin C, Hidalgo S (2011) Petrological analysis of the pre-eruptive magmatic process prior to the 2006 explosive eruptions at Tungurahua volcano (Ecuador). Journal of Volcanology and Geothermal Research 199:69-84. https://doi.org/10.1016/j.jvolgeores.2010.10.010

Shea T, Gurioli L, Larsen JF, Houghton BF, Hammer JE, Cashman KV (2010) Linking experimental and natural vesicle textures in Vesuvius 79 AD white pumice. J Volcanol Geotherm Res 192, 69-84.

https://doi.org/10.1016/j.jvolgeores.2010.02.013

Shields JK, Mader HM, Pistone M, Caricchi L, Floess D, Pulitz B (2014) Strain-induced outgassing of three-phase magmas during simple shear. J Geophys Res Solid Earth 119, 6936-6957. https://doi.org/10.1002/2014JB011111

Takeuchi S, Tomiya A, Shinohara H (2009) Degassing conditions for permeable silicic magmas: Implications from decompression experiments with constant rates. Earth Planet Sci Lett 283, 101-110.

https://doi.org/10.1016/j.epsl.2009.04.001

Thomas ME, Neuberg JW, Collinson ASD (2019) Crystals, Bubbles and Melt: Critical Conduit Processes Revealed by Numerical Models, in: Gottsmann J, Neuberg J, Scheu B (Eds.), Volcanic Unrest : From Science to Society, Advances in Volcanology. Springer International Publishing, Cham,155-169. https://doi.org/10.1007/11157_2018_36

van der Zwan FM, Chadwick JP, Troll VR (2013) Textural history of recent basaltic-andesites and plutonic inclusions from Merapi volcano. Contrib Mineral Petrol 166:43-63. https://doi.org/10.1007/s00410-013-0864-7

Varas G, Ramos G, Géminard JC, Vidal V (2015) Flow and fracture in water-saturated, unconstrained granular beds. Front Phys 3. https://doi.org/10.3389/fphy.2015.00044

Widiyantoro S, Ramdhan M, Métaxian JP, Cummins PR, Martel C, Erdmann S, Nugraha AD, Budi-Santoso A, Laurin A, Fahmi AA (2018) Seismic imaging and petrology explain highly explosive eruptions of Merapi Volcano, Indonesia. Sci Rep 8. https://doi.org/10.1038/s41598-018-31293-w 


\begin{tabular}{|c|c|c|c|c|c|}
\hline & $\begin{array}{c}\text { Pressure } \\
\text { (MPa) }\end{array}$ & $\begin{array}{l}\text { Porosity }^{\mathrm{a}} \\
\text { (vol\%) }\end{array}$ & $\begin{array}{l}\text { Gas }^{b} \\
\text { (ppmw) }\end{array}$ & $\begin{array}{l}\text { Phenocrysts } \\
\text { (vol\%) }\end{array}$ & $\begin{array}{c}\text { Crystals } \\
\text { (vol\%) }\end{array}$ \\
\hline \multicolumn{6}{|c|}{ Soufrière Hills } \\
\hline AMO $210 \mathrm{~A}$ & $40(-9,+10)$ & $1.9(1)$ & 0.6 & $34(2)$ & $54(10)$ \\
\hline AMO $210 \mathrm{C}$ & $51(-25,+31)$ & $2.3(2)$ & 0.92 & $34(12)$ & $55(22)$ \\
\hline AMO $210 \mathrm{D}$ & $14(-3,+3)$ & $1.9(1)$ & 0.2 & $31(6)$ & $39(11)$ \\
\hline AMO $210 \mathrm{E}$ & $54(-19,+22)$ & $3.5(0)$ & 1.54 & $48(0.3)$ & $69(9)$ \\
\hline AMO $210 \mathrm{~F}$ & $33(-8,+9)$ & $1.6(1)$ & 0.41 & $50(2)$ & $66(13)$ \\
\hline AMO $210 \mathrm{G}$ & $42(-13,+15)$ & $1.2(3)$ & 0.39 & $40(12)$ & $63(11)$ \\
\hline AMO $210 \mathrm{H}$ & $12(-5,+6)$ & $8.5(1)$ & 0.89 & $39(8)$ & $65(12)$ \\
\hline AMO $210 \mathrm{~L}$ & $46(-13,+14)$ & $1.4(2)$ & 0.52 & $59(3)$ & $77(6)$ \\
\hline AMO $210 Q$ & $41(-7,+7)$ & $3.4(1)$ & 1.14 & $32(1.3)$ & $40(14)$ \\
\hline WP1.095A & $24(-5,+5)$ & $4.3(0)$ & 0.86 & $24(0.4)$ & $52(3)$ \\
\hline WP1.095B & $16(-6,+7)$ & $7.2(0)$ & 0.95 & $32(0.2)$ & $59(9)$ \\
\hline WP1.108A & $31(-5,+5)$ & $2.8(0)$ & 0.72 & $32(0.3)$ & $52(10)$ \\
\hline WP1.108B & $56(-5,+5)$ & $7.8(1)$ & 3.68 & $36(1.1)$ & $48(3)$ \\
\hline WP2.200A & $36(-8,+9)$ & $2.8(0)$ & 0.81 & $42(0.3)$ & $63(19)$ \\
\hline WP2.200B & $31(-2,+2)$ & $3(0)$ & 0.76 & $31(0.7)$ & $42(3)$ \\
\hline WP2.201A & $35(-8,+9)$ & $4.6(0)$ & 1.33 & $45(0.2)$ & $59(10)$ \\
\hline WP2.201B & $69(-14,+15)$ & $2.4(0)$ & 1.36 & $31(0.2)$ & $51(8)$ \\
\hline WP2.329A & $7(-1,+1)$ & $23.6(0)$ & 1.62 & $11(1.2)$ & $27(15)$ \\
\hline WP2.329B & $41(-4,+4)$ & $2.7(1)$ & 0.89 & $51(2)$ & $65(3)$ \\
\hline \multicolumn{6}{|c|}{ Merapi Oct. 26} \\
\hline AME $10 \mathrm{~A} 1$ & $75(-22,+25)$ & $2.3(4)$ & 1.27 & $33(7)$ & $70(11)$ \\
\hline AME $10 \mathrm{~A} 2$ & $100(-34,+38)$ & $1.5(4)$ & 1.12 & $44(8)$ & $79(8)$ \\
\hline AME 10 A3 & $150(-123,+174)$ & $1.2(3)$ & 1.32 & $40(3)$ & $82(11)$ \\
\hline AME 10 A4 & $100(-22,+24)$ & $1.6(5)$ & 1.16 & $45(8)$ & $80(8)$ \\
\hline AME 10 A5 & $73(-25,+29)$ & $2.4(3)$ & 1.32 & $47(5)$ & $76(6)$ \\
\hline AME 10 A6 & $58(-12,+13)$ & $3.1(2)$ & 1.32 & $46(3)$ & $72(5)$ \\
\hline AME 10 B1 & $158(-48,+53)$ & $0.9(4)$ & 1.03 & $41(9)$ & $80(10)$ \\
\hline AME 10 B2 & $63(-11,+12)$ & $2.3(3)$ & 1.05 & $50(5)$ & $72(8)$ \\
\hline AME 10 B4 & $268(-106,+118)$ & $0.6(4)$ & 1.14 & $36(6)$ & $87(6)$ \\
\hline AME 10 B5 & $260(-153,+184)$ & $0.4(5)$ & 0.73 & $44(13)$ & $87(12)$ \\
\hline AME $10 \mathrm{C} 1$ & $159(-57,+64)$ & $1(1)$ & 1.13 & $38(1)$ & $80(14)$ \\
\hline AME 10 C2 & $141(-31,+33)$ & $0.7(2)$ & 0.69 & $38(5)$ & $81(6)$ \\
\hline AME 10 C3 & $55(-17,+20)$ & $2.8(2)$ & 1.16 & $46(3)$ & $70(10)$ \\
\hline AME $10 \mathrm{C} 4$ & $77(-24,+27)$ & $1.4(3)$ & 0.78 & $44(7)$ & $77(7)$ \\
\hline AME 10 D1 & $107(-25,+27)$ & $1.1(3)$ & 0.88 & $44(4)$ & $79(9)$ \\
\hline AME 10 D2 & $85(-37,+43)$ & $1.4(5)$ & 0.88 & $42(11)$ & $79(11)$ \\
\hline AME 10 D3 & $64(-37,+47)$ & $2(8)$ & 0.96 & $34(20)$ & $69(27)$ \\
\hline AME 10 D4 & $63(-14,+15)$ & $2.8(5)$ & 1.34 & $42(12)$ & $71(10)$ \\
\hline AME 10 E1 & $75(-23,+26)$ & $1.2(2)$ & 0.67 & $42(6)$ & $74(11)$ \\
\hline AME 10 E2 & $202(-67,+74)$ & $0.9(4)$ & 1.26 & $57(4)$ & $88(4)$ \\
\hline AME 10 E3 & $59(-11,+12)$ & $2(3)$ & 0.86 & $43(9)$ & $74(8)$ \\
\hline AME 10 E4 & $77(-15,+16)$ & $1.9(5)$ & 1.1 & $45(10)$ & $72(8)$ \\
\hline AME 10 E5 & $227(-78,+87)$ & $0.5(4)$ & 0.85 & $45(12)$ & $86(11)$ \\
\hline
\end{tabular}




\begin{tabular}{|c|c|c|c|c|c|}
\hline AME 10 F1 & $12(-5,+5)$ & $2.3(20)$ & 0.2 & $21(23)$ & $54(17)$ \\
\hline AME 10 G1 & $42(-16,+18)$ & $2.3(2)$ & 0.76 & $52(5)$ & $75(7)$ \\
\hline AME $10 \mathrm{G} 2$ & $75(-54,+75)$ & $1.1(2)$ & 0.78 & $51(6)$ & $82(11)$ \\
\hline AME 10 G3 & $44(-21,+25)$ & $0.3(15)$ & 0.48 & $41(9)$ & $70(12)$ \\
\hline AME $10 \mathrm{GA}$ & $94(-25,+28)$ & $2.8(1)$ & 0.89 & $48(10)$ & $81(9)$ \\
\hline AME $10 \mathrm{~GB}$ & $196(-80,+92)$ & $1.6(1)$ & 0.86 & $47(8)$ & $88(8)$ \\
\hline \multicolumn{6}{|l|}{ Tungurahua } \\
\hline 1 & $0.8(-0.2,+0.4)$ & $36.8(3)$ & 0.33 & $15(21)$ & $55(12)$ \\
\hline 2 & $0.5(-0.1,+0.1)$ & $0(8)$ & 0 & $46(10)$ & $73(9)$ \\
\hline 4 & $0.9(-0.2,+0.3)$ & $0.9(11)$ & 0.01 & $42(14)$ & $67(13)$ \\
\hline 6 & $0.5(-0.1,+0.2)$ & $0.3(30)$ & 0.001 & $39(36)$ & $70(32)$ \\
\hline 7.5 & $0.6(-0.2,+0.3)$ & $0.8(9)$ & 0.004 & $30(12)$ & $62(12)$ \\
\hline 11 & $3(-1,+1)$ & $0(1)$ & 0 & $25(1.4)$ & $44(5)$ \\
\hline 12 & $109(-63,+91)$ & $0.3(1)$ & 0.24 & $34(0.8)$ & $38(5)$ \\
\hline 13 & $5(-2,+9)$ & $44.2(1)$ & 2.53 & $32(2)$ & $48(14)$ \\
\hline 14 & $31(-17,+68)$ & $8.5(4)$ & 2.07 & $38(4)$ & $45(6)$ \\
\hline 16 & $1.6(-0.4,+0.5)$ & $15.7(4)$ & 0.21 & $31(3)$ & $55(5)$ \\
\hline 17 & $24(-8,+16)$ & $1.7(2)$ & 0.29 & $36(6)$ & $43(6)$ \\
\hline 18 & $34(-15,+41)$ & $6.1(1)$ & 1.57 & $34(2)$ & $43(6)$ \\
\hline 20 & $66(-14,+20)$ & $1.5(2)$ & 0.69 & $31(3)$ & $36(4)$ \\
\hline 21 & $5(-3,+8)$ & $3.2(2)$ & 0.12 & $36(3)$ & $51(10)$ \\
\hline 22 & $2(-1,+5)$ & $0(4)$ & 0 & $26(3)$ & $48(15)$ \\
\hline 26 & $51(-36,+149)$ & $8(3)$ & 3.14 & $32(2)$ & 39 (9) \\
\hline 27 & $15(-5,+10)$ & $8.5(3)$ & 1.01 & $34(5)$ & $42(8)$ \\
\hline 28 & $5(-2,+9)$ & $36.5(3)$ & 1.86 & $29(6)$ & $45(12)$ \\
\hline 29 & $30(-17,+82)$ & $7.7(1)$ & 1.77 & $30(0.8)$ & $36(6)$ \\
\hline 30 & $4(-1,+2)$ & $51.7(1)$ & 3.14 & $23(4)$ & $41(8)$ \\
\hline 34 & $1.2(-0.3,+0.4)$ & $45(3)$ & 0.69 & $25(2)$ & $53(6)$ \\
\hline 35 & $4(-1,+2)$ & $11.5(3)$ & 0.4 & $28(3)$ & $46(5)$ \\
\hline 36 & $5(-1,+2)$ & $8.1(1)$ & 0.33 & $30(2)$ & $47(7)$ \\
\hline 38 & $31(-14,+38)$ & $10.6(1)$ & 2.62 & $39(2)$ & $45(4)$ \\
\hline 39 & $31(-17,+67)$ & $1.5(2)$ & 0.33 & $34(5)$ & $40(7)$ \\
\hline 40 & $10(-0.1,+0.1)$ & $25.7(2)$ & 2.43 & $38(2)$ & $49(2)$ \\
\hline 41 & $174(-79,+26)$ & $0.3(2)$ & 0.4 & $26(3)$ & $32(4)$ \\
\hline
\end{tabular}

${ }^{\text {a }}$ Values at 0 are $<0.1 \mathrm{vol} \%$ and errors at 0 are $<1 \%$.

${ }^{\mathrm{b}}$ Values at 0 are $<0.001 \mathrm{ppm}$ per weight. 


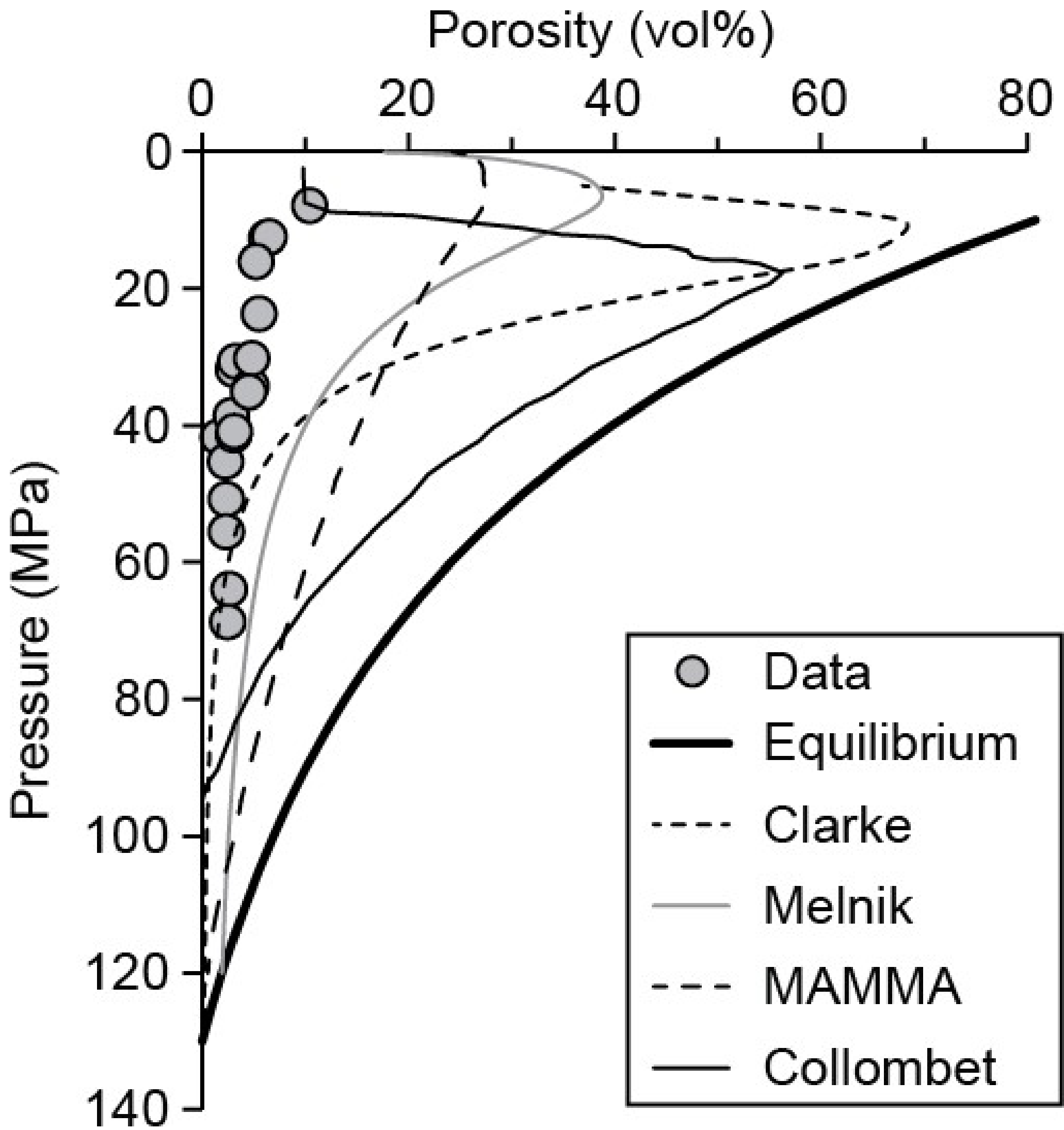




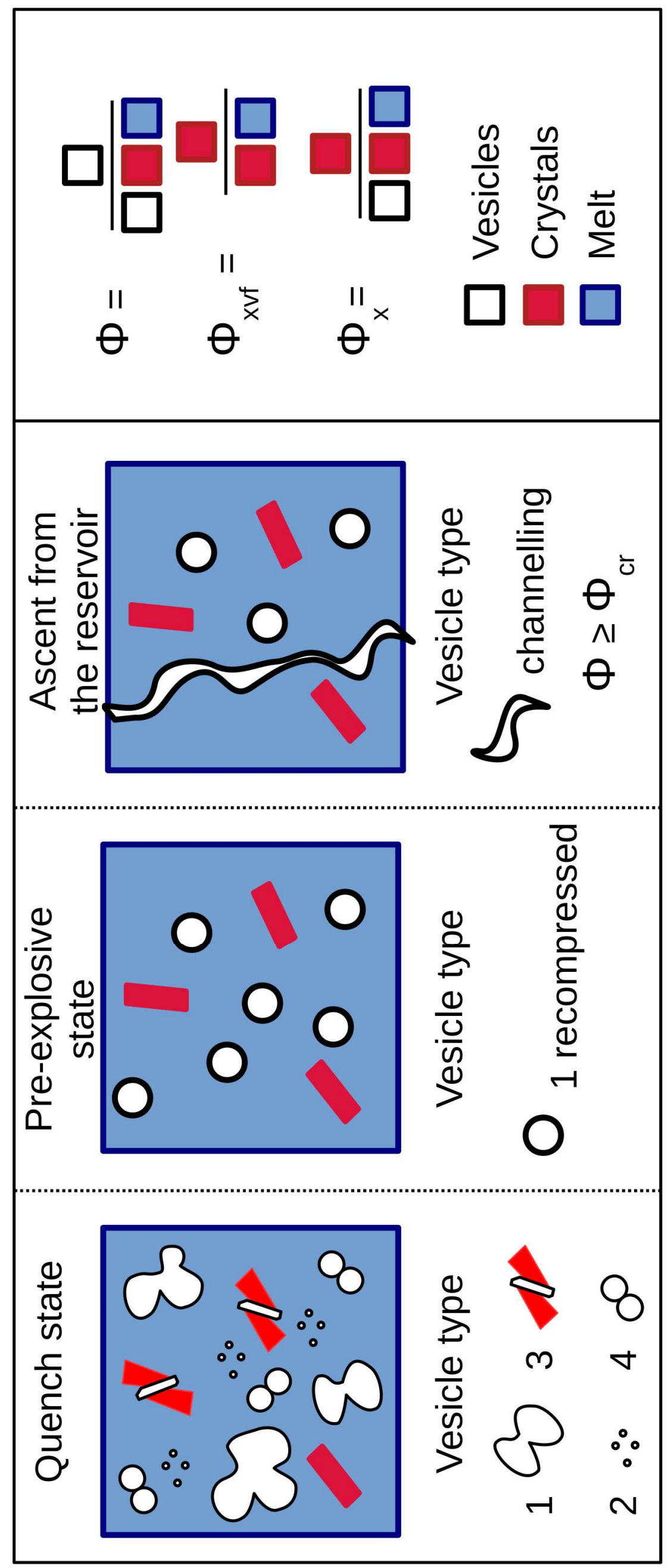



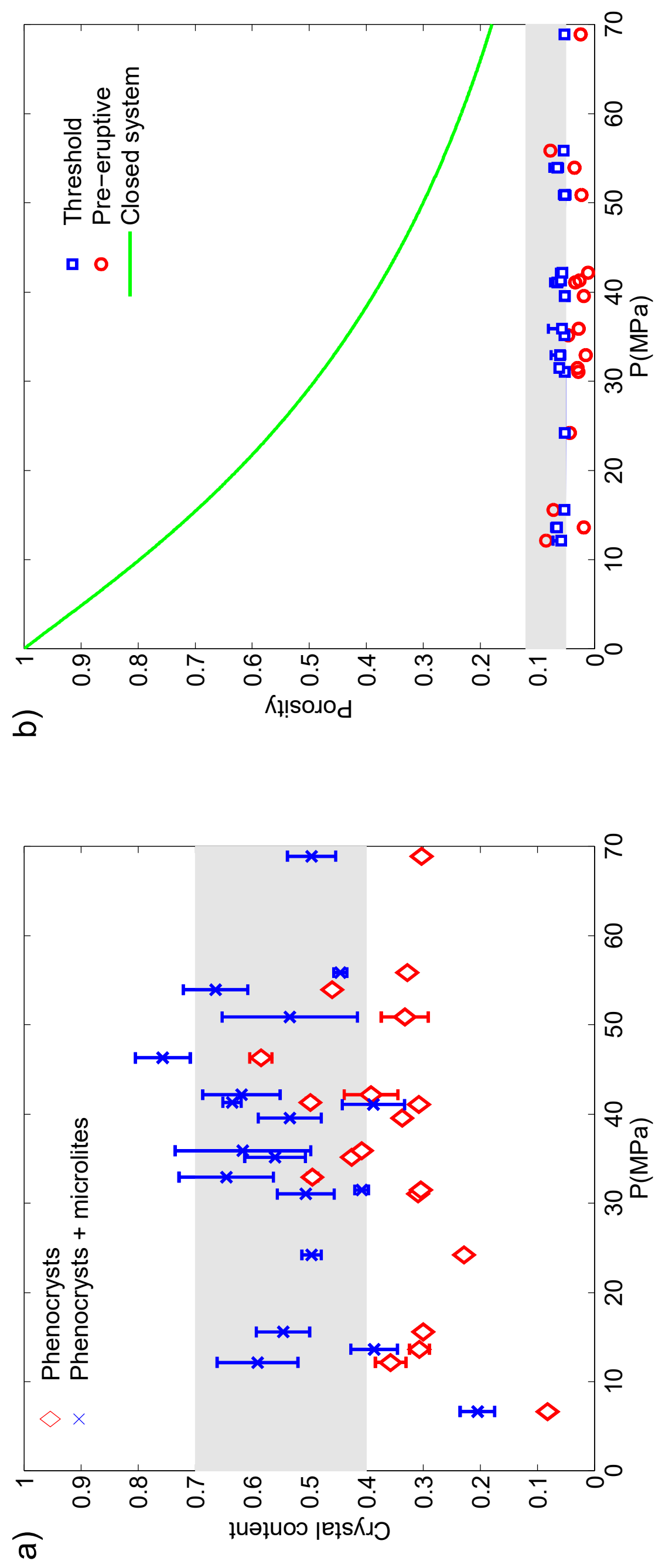


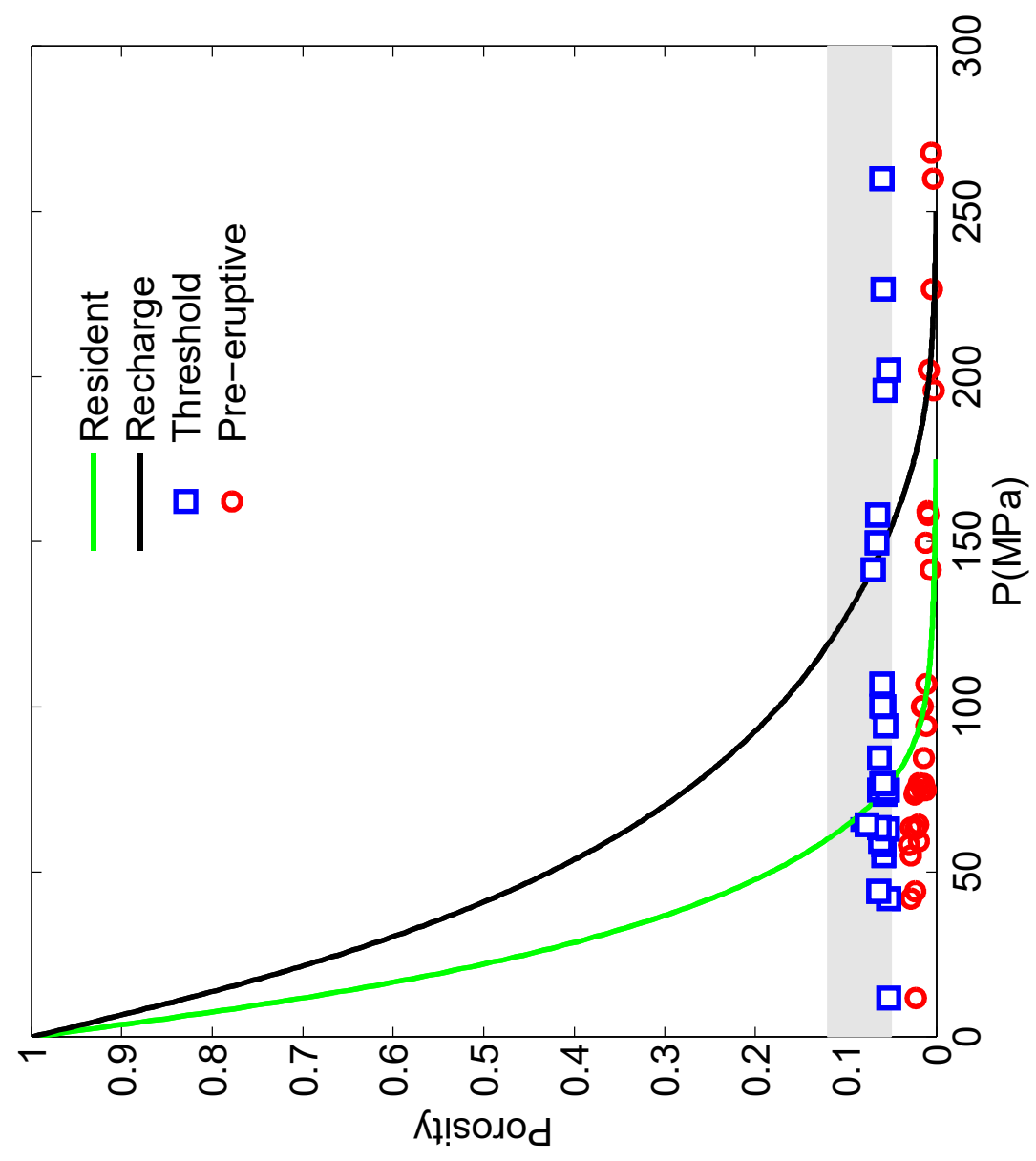

$\widehat{a}$

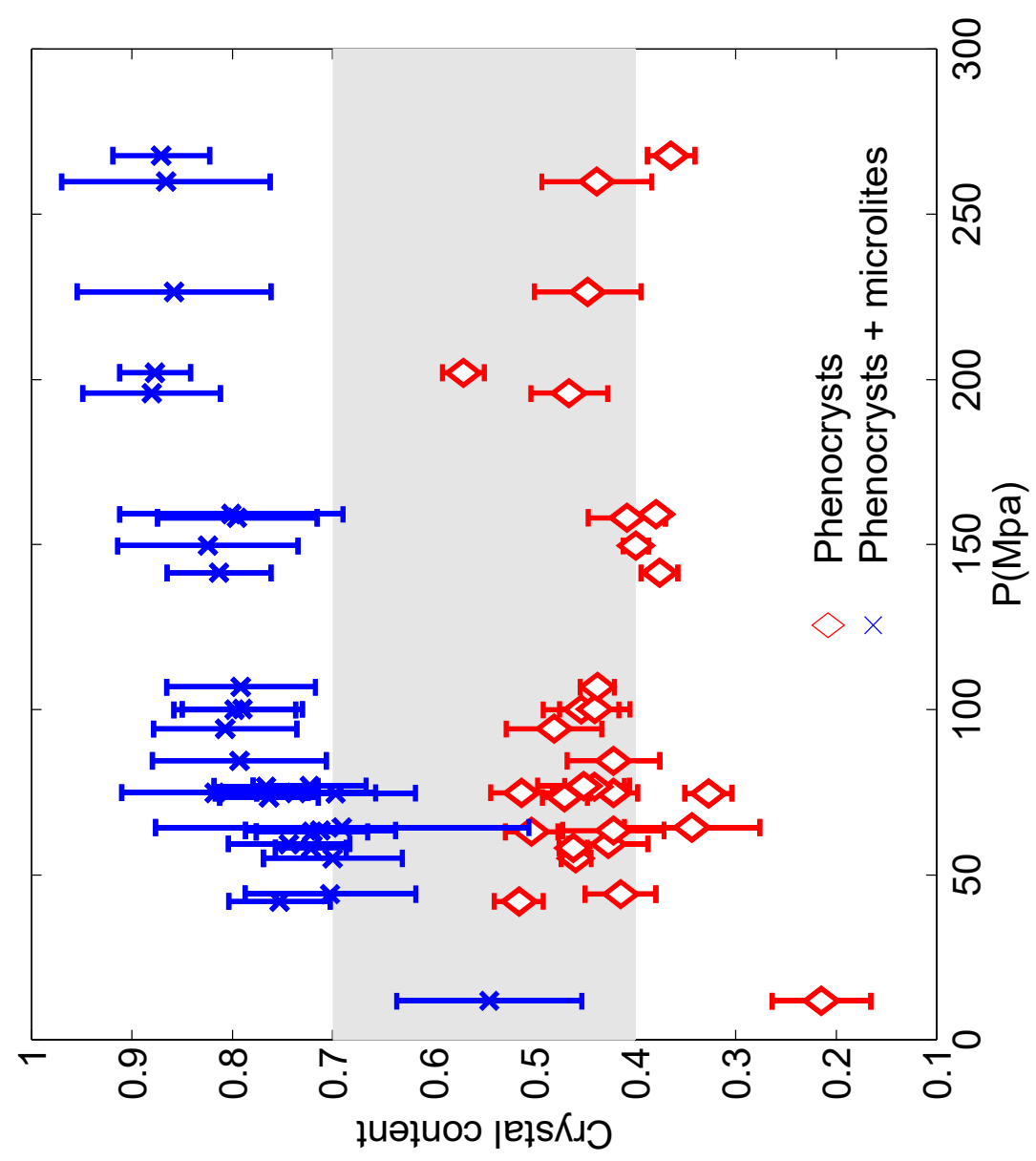




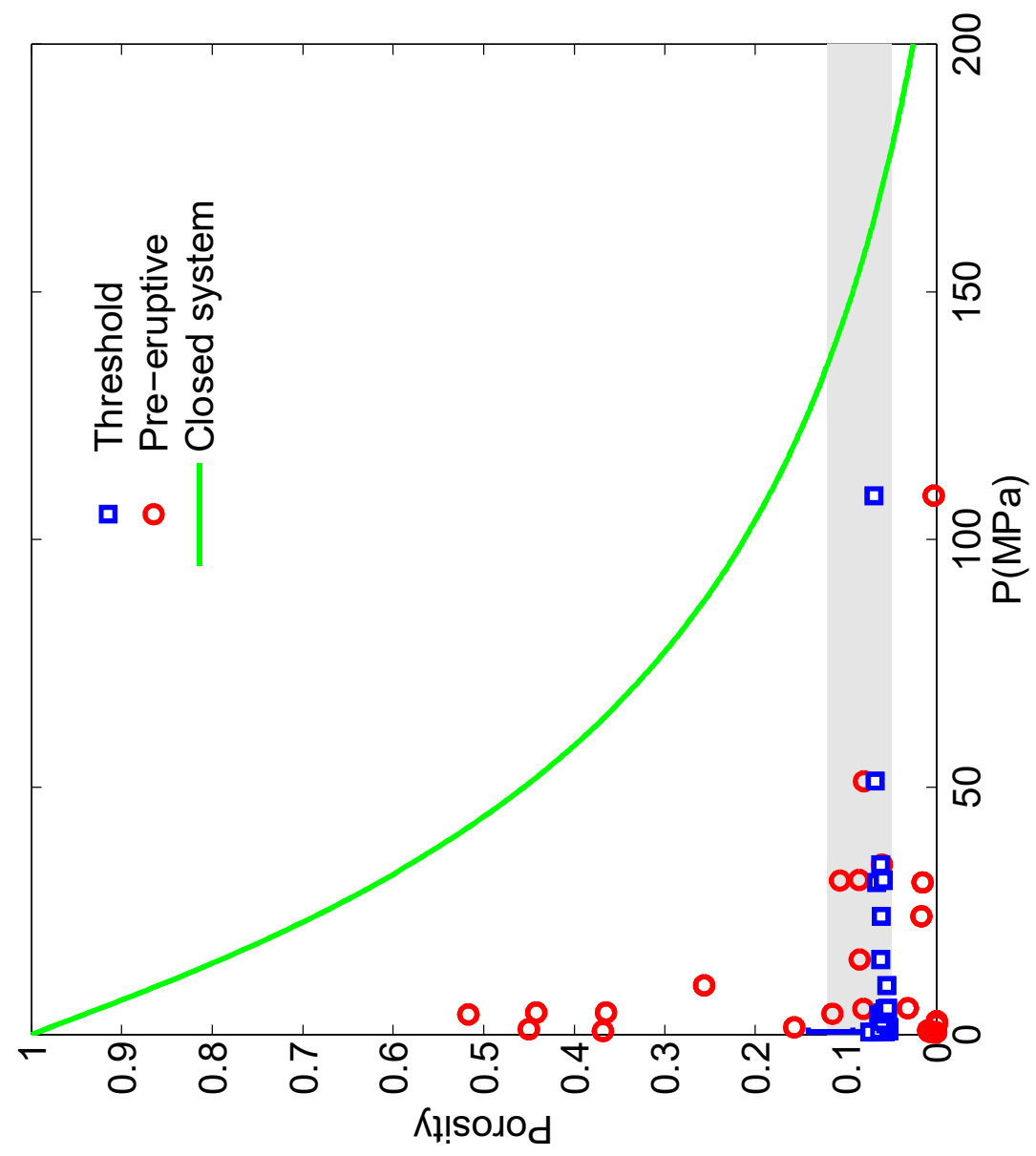

อ

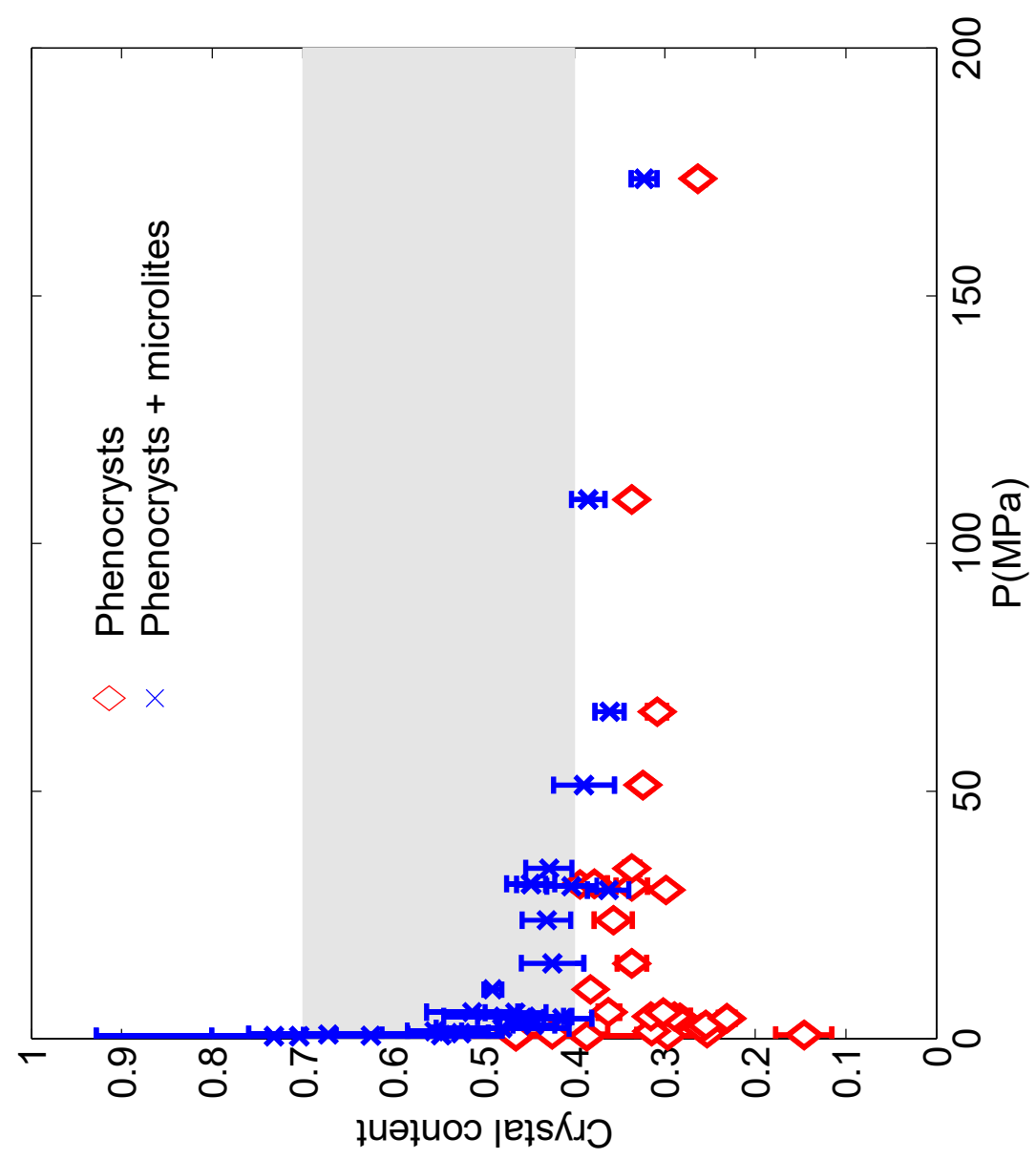




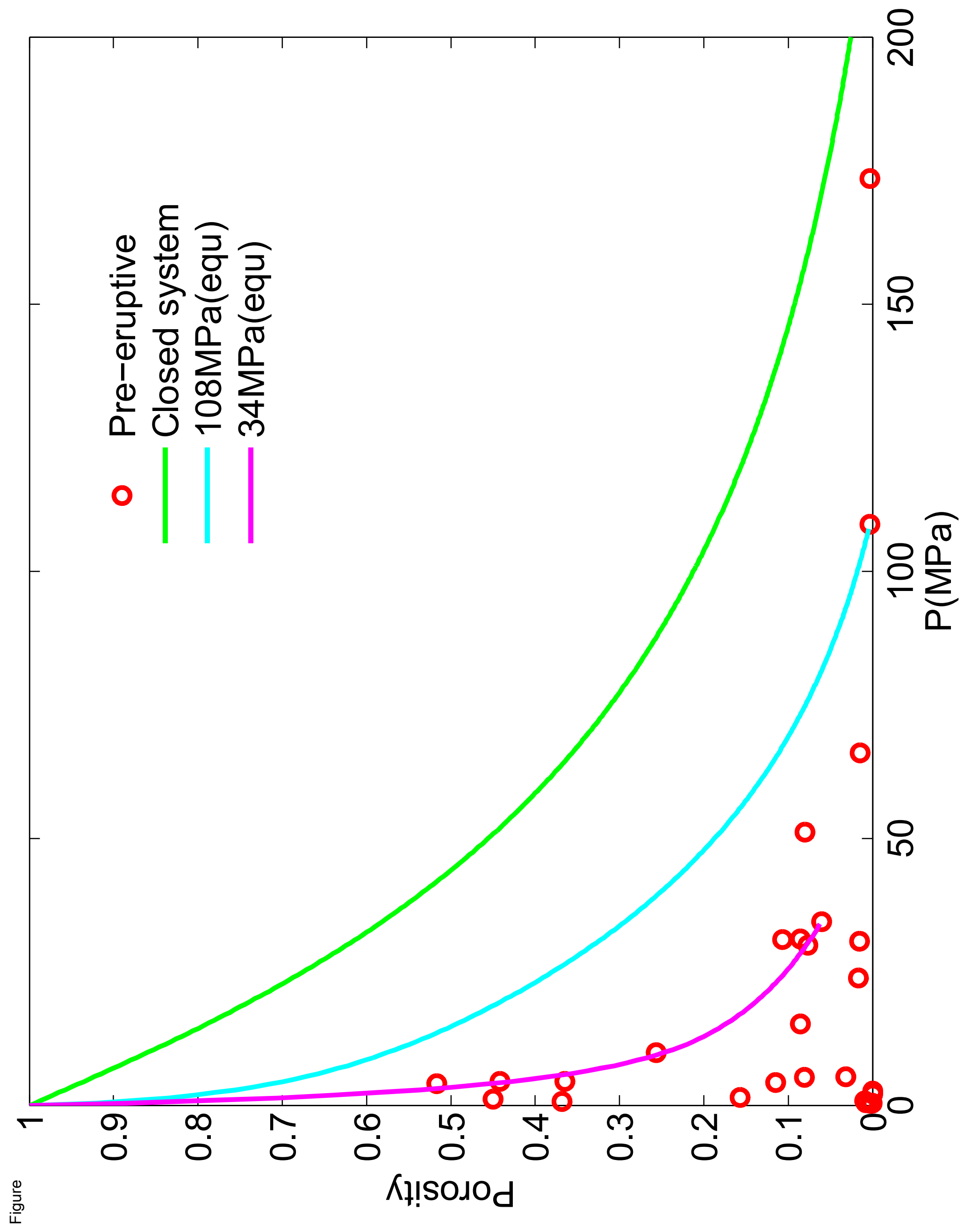




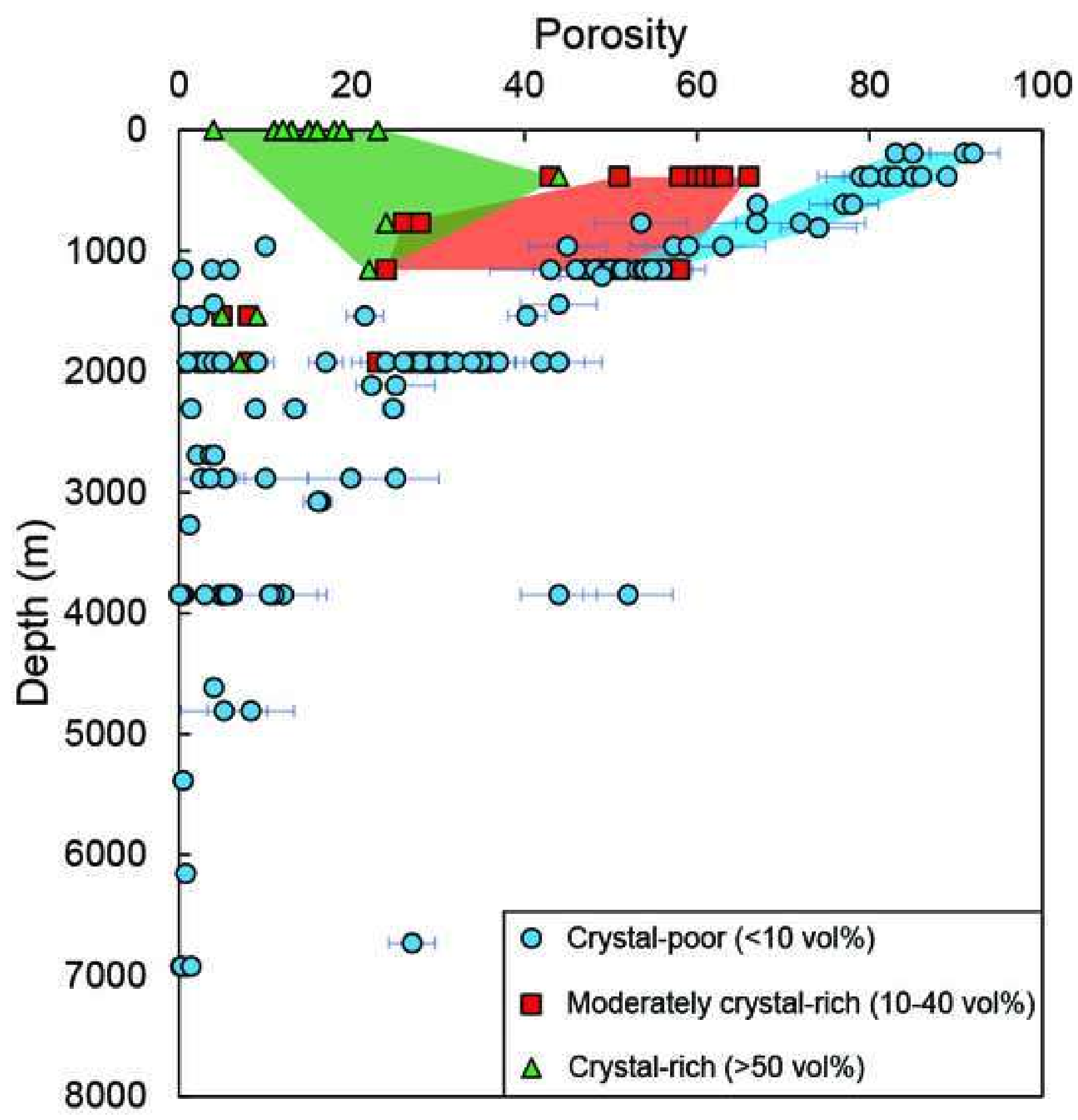

